JOZÉLIA GOMES PACHECO FERREIRA

\title{
ORGANIZAÇÃO DAS PROJEÇÕES DA ÁREA TEGMENTAL VENTRAL PARA O COMPLEXO VTA-SUBSTÂNCIA NEGRA E PARA O HIPOTÁLAMO NO RATO E ESTUDO DA EXPRESSÃO DOS SUBSTRATOS DO RECEPTOR DE INSULINA EM NEURÔNIOS DA VTA QUE SE PROJETAM PARA O ESTRIADO
}

Tese apresentada ao Programa de Pós-Graduação em Fisiologia e Biofísica do Instituto de Ciências Biomédicas da Universidade de São Paulo, para obtenção do Título de Doutor em Ciências.

Área de concentração: Fisiologia Humana

Orientador: Profa. Dra. Sara Joyce ShammahLagnado

São Paulo

2009 


\section{RESUMO}

FERREIRA, J.G.P. Organização das projeções da área tegmental ventral para o complexo VTA-substância negra e para o hipotálamo no rato e estudo da expressão dos substratos do receptor de insulina em neurônios da VTA que se projetam para o estriado. Tese (Doutorado em Ciências) - Instituto de Ciências Biomédicas da Universidade de São Paulo, São Paulo, 2009.

A área tegmental ventral (VTA) está implicada em mecanismos de recompensa e, mais recentemente, é tida como um centro adicional de detecção de sinais metabólicos periféricos. $\mathrm{Na}$ primeira etapa deste trabalho, investigamos as conexões intrínsecas da VTA para o complexo VTA-substância negra utilizando como traçador anterógrado a leucoaglutinina do Phaseolus vulgaris (PHA-L). Os resultados obtidos sugerem que a VTA dorsolateral se projeta para ela mesma e para a porção dorsal da substância negra compacta e núcleo retrorrubral; a VTA ventrolateral inerva principalmente o núcleo interfascicular; os componentes da VTA caudomedial (núcleos interfascicular, paranigral e caudal linear) estão interconectados; o pólo caudal da VTA envia projeções robustas e bilaterais para praticamente todo o complexo VTAsubstância negra, terminando tanto na porção dorsal quanto na porção ventral da substância negra compacta; aposições entre varicosidades imunorreativas para PHA-L e neurônios imunorreativos para tirosina hidroxilase $(\mathrm{TH}+)$ foram observadas. Numa segunda etapa, investigamos as projeções da VTA para o hipotálamo. A importância de mecanismos dopaminérgicos no hipotálamo lateral já é reconhecida há tempo, tendo sido implicados na ingestão de alimentos, na indução de preferência condicionada a lugar e na aquisição de respostas condicionadas apetitivas. Os resultados de nosso estudo sugerem que: 1) A VTA se projeta principalmente para a área pré-óptica lateral, a área hipotalâmica lateral, a região subfornical posterior e os núcleos dorsomedial e posterior do hipotálamo. Deve ser ressaltado que a área hipotalâmica lateral é mais densamente inervada em sua porção rostral do que em suas porções tuberal ou posterior. A VTA origina ainda aferências modestas para a área pré-óptica medial e para as regiões perfornical e supramamilar; 2) Há evidências de uma organização topográfica das projeções da VTA para o hipotálamo. Em particular, as projeções para o núcleo dorsomedial e a região subfornical posterior se originam primariamente da VTA caudomedial, sendo que a região rostrodorsal da VTA evita totalmente estes distritos hipotalâmicos; 3) Aposições entre terminais imunorreativos para PHA-L e neurônios imunorreativos para orexina ou hormônio concentrador de melanina foram observadas, porém são pouco frequentes; 4) Em experimentos de dupla marcação anterógrada com injeções de amino dextrana biotina no accumbens e PHA-L na VTA, foi observado embricamento destas projeções na área pré-óptica lateral e região anterior do hipotálamo lateral. Numa terceira etapa, investigamos a colocalização do substrato do receptor de insulina do tipo I (IRS-1), do IRS-1 fosforilado e da fosfatidilinositol-3 quinase (PI3K) com TH ou com a subunidade B da toxina colérica $(\mathrm{CTb})$ após sua injeção no estriado. Nossos dados sugerem que: 1) A grande maioria dos neurônios dopaminérgicos do complexo VTA-substância negra expressa IRS-1; 2) Injeções na concha ou no cerne do accumbens resultaram numa porcentagem similar de células duplamente marcadas para CTb/IRS-1. Um número significativo de células foram duplamente marcadas para $\mathrm{CTb} / \mathrm{PI} 3 \mathrm{~K}$; 3) Injeções no estriado dorsal resultaram em células duplamente marcadas para 
CTb/PI3K e CTb/IRS-1 fosforilado; 4) A marcação para IRS-1 foi identificada no núcleo das células, diferentemente do observado por Folli e colaboradores (J. Neurosci. 14: 6412-6422, 1994) que relataram esta marcação no citosol.

Palavras-chave: Dopamina. Substância negra. Núcleo retrorrubral. Área pré-óptica lateral. Área hipotalâmica lateral. Substratos do receptor de insulina. 


\begin{abstract}
FERREIRA, J.G.P. Organization of the ventral tegmental area projections to the VTAnigral complex and to the hypothalamus in the rat and VTA neurons projecting to the accumbens express insulin receptor substrates. $\mathrm{PhD}$ thesis (Physiology) - Biomedical Sciences Institute, the University of São Paulo, São Paulo, 2009.
\end{abstract}

The ventral tegmental area (VTA) is involved in reward mechanisms and, more recently, has been identified as an additional center detecting peripheral metabolic signals. In the first part of this work, the projections from the VTA to the VTA-substantia nigra complex were investigated using the anterograde tracer Phaseolus vulgaris leucoagglutinin (PHA-L). The results suggest that the dorsolateral VTA projects to itself and to the dorsal portion of the substantia nigra compacta and retrorubral nucleus. The ventrolateral VTA innervates mainly the interfascicular nucleus. The components of the caudomedial VTA (interfascicular, caudal linear and paranigral nuclei) are interconnected. The caudal pole of the VTA sends robust and bilateral projections to almost the entire VTA-substantia nigra complex, ending in both the dorsal and ventral tiers of the substantia nigra compacta. Appositions between PHA-L immunoreactive varicosities and neurons immunoreactive to tyrosine hydroxylase $(\mathrm{TH}+)$ were often observed. In the second part of this work, the VTA projections to the hypothalamus were investigated. The importance of dopaminergic mechanisms in the lateral hypothalamus has long been acknowledged, they are involved in food intake, conditioned place preference, acquisition of appetitive conditioned responses and locomotor activity. The present results suggest that: 1) the VTA projects mainly to the lateral preoptic area and lateral hypothalamic area, the posterior subfornical region as well as to the dorsomedial and posterior hypothalamic nuclei. The lateral hypothalamic area is more densely innervated at rostral levels than at tuberal or caudal levels. The VTA also provides modest inputs to the medial preoptic area, the perifornical area and to the supramammillary region; 2) VTA projections to the hypothalamus display some topographical organization. In particular, projections to the dorsomedial nucleus and posterior subfornical region originate primarily from the caudomedial VTA, whereas the rostrodorsal VTA avoids these hypothalamic districts; 3) Appositions between PHA-L immunoreactive varicosities and neurons immunoreactive to orexin or melanin-concentrating hormone were observed, but they are uncommon; and 4) In double labeling experiments with injections of anterograde biotin dextran amine into the accumbens and PHA-L into the VTA, an extensive overlap of these projections was observed in the lateral preoptic area and anterior part of the lateral hypothalamic area. In the third part of this work, we have investigated the co-localization of the insulin receptor substrate type I (IRS-1), IRS-1 phosphorylated and phosphatidylinositol-3 kinase $(\mathrm{PI} 3 \mathrm{~K})$ with $\mathrm{TH}$ or cholera toxin $\mathrm{B}$ subunit $(\mathrm{CTb})$ injected into either the accumbens or the caudate-putamen. Our data suggest that: 1) The vast majority of dopaminergic neurons of the VTA-substantia nigra complex express IRS-1; 2) Injections into the shell or core of the accumbens resulted in a similar percentage of double-labeled cells for CTb/IRS-1. A significant number of cells were double-labeled for $\mathrm{CTb} / \mathrm{PI} 3 \mathrm{~K}$ and 3) Injections in the dorsal striatum resulted in cells that were double-labeled for $\mathrm{CTb} / \mathrm{PI} 3 \mathrm{~K}$ and $\mathrm{CTb} / \mathrm{IRS}-1$ phosphorylated, 4) The IRS-1 immunolabeling was localized in the nucleus of cells, unlike the cytosolic labeling observed by Folli and colleagues (J. Neurosci. 14: 6412-6422, 1994). 
Keywords: Dopamine. Substantia nigra. Retrorubral nucleus. Lateral preoptic area. Lateral hypothalamic area. Insulin receptor substrates. 


\section{PARTE 1 - PROJEÇÕES DA VTA PARA O COMPLEXO VTA-SUBSTÂNCIA NEGRA}

\subsection{INTRODUÇÃO}

A área tegmental ventral (VTA) está implicada em mecanismos de recompensa e em processos cognitivos (GOLDMAN-RAKIC, 1999; GOLDMAN-RAKIC et al., 2004; IKEMOTO, 2007). Ela ocupa a região ventromedial do mesencéfalo compreendida entre o núcleo interpeduncular, a substância negra e o núcleo rubro (HALLIDAY e TÖRK, 1986; OADES e HALLIDAY, 1987). Alberga o grupamento dopaminérgico A10 (DAHLSTRÖM e FUXE, 1964; BJÖRKLUND e LINDVALL, 1984) e também numerosos neurônios GABAérgicos (STEFFENSEN et al., 1998; OLSON e NESTLER, 2007).

Suas principais relações anatômicas já foram delineadas em estudos clássicos. A VTA recebe aferências de um grande número de estruturas, a maioria delas do cerne isodendrítico (PHILLIPSON, 1979b; GEISLER e ZAHM, 2005) e dá origem ao sistema mesocorticolímbico, cujos principais alvos são o estriado ventral, o cortex pré-frontal, a área septal, a amígdala e a habênula lateral, entre outras estruturas (FALLON e MOORE, 1978; BECKSTEAD et al., 1979; SWANSON, 1982; BJÖRKLUND e LINDVALL, 1984). Foi ainda demonstrado que as projeções telencefálicas da VTA são topograficamente organizadas. Elas obedecem a um plano de organização médio-lateral, de modo que distritos mediais da VTA inervam regiões mediais do telencéfalo e distritos laterais da VTA invervam regiões laterais do telencéfalo (FALLON e MOORE, 1978; FALLON et al., 1978; BECKSTEAD et al., 1979; KLITENICK et al., 1992) e que setores rostrodorsais da VTA projetam-se preferencialmente para territórios corticais e setores ventrocaudais da VTA, principalmente para áreas subcorticais mesolímbicas (SCHEIBNER e TÖRK, 1987; OADES e HALLIDAY, 1987). Em estudos de rastreamento retrógrado observou-se que as projeções da VTA para o accumbens obedecem a um padrão dorso-ventral invertido de forma que os setores mais dorsais da VTA se projetam para as porções mais ventrais do accumbens e os setores mais ventrais da VTA estão relacionados com os setores mais dorsais do accumbens (BROG et al., 1993; HASUE e SHAMMAH-LAGNADO, 2002). Mais recentemente, Sesack e colaboradores, em uma série de estudos ultraestruturais, forneceram informações adicionais sobre a circuitaria da VTA, que indicam que a sua organização é mais específica do que se acreditava previamente (FIELDS et al., 2007). De fato, aferências para a VTA estabelecem contato sináptico com subpopulações neuronais distintas com base no tipo do 
neurotransmissor que elas expressam e no alvo para o qual elas se projetam. Por exemplo, fibras do córtex pré-frontal terminam seletivamente em neurônios dopaminérgicos da VTA que se projetam de volta para o córtex préfrontal e em neurônios GABAérgicos da VTA que inervam o accumbens (CARR e SESACK, 2000).

Apesar da importância funcional da VTA e do sistema mesotelencefálico que ela origina em mecanismos de recompensa cerebral e em processos motivacionais e cognitivos, alguns aspectos desta circuitaria são até hoje pouco conhecidos. Neste trabalho, vamos descrever, em uma primeira etapa, as projeções da VTA para o complexo VTA-substância negra (FERREIRA et al., 2008).

Foi proposto em bases eletrofisiológicas e farmacológicas que neurônios GABAérgicos da VTA, via conexões locais, podem inibir tonicamente presumíveis neurônios dopaminérgicos, ou seja que a liberação de dopamina é controlada em parte por mecanismos desinibitórios (JOHNSON e NORTH, 1992; STEFFENSEN et al., 2006). Entretanto, existem poucos dados na literatura a respeito da circuitaria intrínseca da VTA ou de suas projeções para outros componentes do complexo VTA-substância negra, a saber a substância negra compacta (SNc) e o núcleo retrorrubral (RR). Phillipson (1979a) relatou, em um estudo utilizando a técnica de Golgi, que neurônios da VTA às vezes emitem um colateral que termina próximo do corpo celular de origem, porém nem a densidade e nem a organização detalhada destas conexões intra-VTA puderam ser avaliadas neste estudo. Beckstead e colaboradores (1979), em um estudo utilizando a técnica radioautográfica, observaram uma marcação na SNc ipsilateral e em partes adjacentes da substância negra reticulada após injeções na VTA. Entretanto, essa técnica não permite diferenciar terminações axonais de fibras de passagem.

Em termos mais gerais, uma investigação das projeções locais da VTA para o complexo VTA-substância negra tem implicações para compreender o fluxo de informações nos núcleos da base. Embora a VTA seja composta de núcleos citoarquitetonicamente distintos (PHILLIPSON, 1979a; OADES e HALLIDAY, 1987), ela é usualmente vista como uma entidade anatômica. Recentemente, Ikemoto (2007), usando como critério a topografia médio-lateral das projeções da VTA para o estriado ventral, subdividiu a VTA em duas regiões principais. A VTA caudomedial, que inclui o núcleo interfascicular, o núcleo caudal linear e o núcleo paranigral, termina seletivamente no estriado ventromedial, e a VTA lateral, correspondendo ao núcleo parabraquial pigmentoso, inerva principalmente o estriado ventrolateral (BROG et al., 1993; HASUE e SHAMMAH-LAGNADO, 2002; DEL FAVA et al., 2007; IKEMOTO, 2007). Evidências da literatura sugerem que estes dois sistemas 
mesoestriatais têm funções diferentes em mecanismos de recompensa. O sistema mesoestriatal ventromedial está envolvido no aprendizado de uma associação estímuloresultado e o sistema mesoestriatal ventrolateral, no aprendizado de uma associação estímuloação (IKEMOTO, 2007). Através de um elo sináptico na VTA lateral, o estriado ventromedial pode influenciar a atividade do estriado ventrolateral, que por sua vez, através da SNc, pode afetar a atividade do estriado dorsal (NAUTA e DOMESICK, 1978; HABER et al., 2000). Assim, através de alças espiraladas estriado-nigro-estriatais, aspectos motivacionais podem interagir com processos cognitivos e estes com funções motoras. A análise das projeções da VTA para o complexo VTA-substância negra poderia esclarecer se populações neuronais relacionadas com o mesmo domínio estriatal estão preferencialmente interconectadas e/ou se as conexões observadas podem mediar interações entre populações neuronais que se projetam para diferentes domínios estriatais.

Obs.: Esta primeira etapa do trabalho foi publicada recentemente - FERREIRA et al., 2008. 
A análise da série processada para dupla reação imunoistoquímica para PHA-L/TH confirmou que a marcação anterógrada produzida por injeções na VTA está localizada em distritos ricos em TH contendo os grupamentos A8, A9 e A10. Foram observados dois tipos diferentes de fibras: uma com pequeno calibre e varicosidades finas (Figura 13D) e outra de calibre mais grosso e com varicosidades maiores (Figura 13B; ver também Gerfen et al., 1987a). Varicosidades dos 2 tipos foram, às vezes, vistas apostas a um dendrito ou pericário imunorreativo para TH na VTA, SNc e RR (Figura 13). 


\section{REFERÊNCIAS BIBLIOGRÁFICAS*}

ABIZAID, A.; LIU, Z.W.; ANDREWS, Z.B.; SHANABROUGH, M.; BOROK, E.; ELSWORTH, J.D.; ROTH, R.H.; SLEEMAN, M.W.; PICCIOTTO, M.R.; TSCHOP, M.H.; GAO, X.B.; HORVATH, T.L. Ghrelin modulates the activity and synaptic input organization of midbrain dopamine neurons while promoting appetite. J. Clin. Invest., v. 116, p. 32293239, 2006.

ABRAHAMSON, E.E.; LEAK, R.K.; MOORE, R.Y. The suprachiasmatic nucleus projects to posterior hypothalamic arousal systems. Neuroreport, v. 12, p. 435-440, 2001.

ALBERTO, C.O.; TRASK, R.B.; QUINLAN, M.E.; HIRASAWA, M. Bidirectional dopaminergic modulation of excitatory synaptic transmission in orexin neurons. J. Neurosci., v. 26, p. 10043-10050, 2006.

ALLISON, D.W.; OHRAN, A.J.; STOBBS, S.H.; MAMELI, M.; VALENZUELA, C.F.; SUDWEEKS, S.N.; RAY, A.P.; HENRIKSEN, S.J.; STEFFENSEN, S.C. Connexin-36 gap junctions mediate electrical coupling between ventral tegmental area GABA neurons. Synapse, v.60, p. 20-31, 2006.

ANAND, B.K.; BROBECK, J.R. Hypothalamic control of food intake in rats and cats. Yale J. Biol. Med., v. 24, p. 123-140, 1951.

ARAKI, E.; LIPES, M.A.; PATTI, M.E.; BRUNING, J.C.; HAAG, B., 3RD; JOHNSON, R.S.; KAHN, C.R. Alternative pathway of insulin signaling in mice with targeted disruption of the IRS-1 gene. Nature, v. 372, p. 186-190, 1994.

ARTS, M.P.; GROENEWEGEN, H.J.; VEENING, J.G.; COOLS, A.R. Efferent projections of the retrorubral nucleus to the substantia nigra and ventral tegmental area in cats as shown by anterograde tracing. Brain Res. Bull., v. 40, p. 219-228, 1996.

BACHNER, D.; KREIENKAMP, H.; WEISE, C.; BUCK, F.; RICHTER, D. Identification of melanin concentrating hormone $(\mathrm{MCH})$ as the natural ligand for the orphan somatostatin-like receptor 1 (SLC-1). FEBS Lett., v. 457, p. 522-524, 1999.

BADO, A.; LEVASSEUR, S.; ATTOUB, S.; KERMORGANT, S.; LAIGNEAU, J.P.; BORTOLUZZI, M.N.; MOIZO, L.; LEHY, T.; GUERRE-MILLO, M.; LE MARCHANDBRUSTEL, Y.; LEWIN, M.J. The stomach is a source of leptin. Nature, v. 394, p. 790-793, 1998.

\footnotetext{
* De acordo com:

ASSOCIAÇÃO BRASILEIRA DE NORMAS TÉCNICAS. NBR 6023: Informação e documentação: referências: elaboração. Rio de Janeiro, 2002.
} 
BALCITA-PEDICINO, J.J.; SESACK, S.R. Orexin axons in the rat ventral tegmental area synapse infrequently onto dopamine and gamma-aminobutyric acid neurons. J. Comp. Neurol., v. 503, p. 668-684, 2007.

BALDO, B.A.; KELLEY, A.E. Amylin infusion into rat nucleus accumbens potently depresses motor activity and ingestive behavior. Am. J. Physiol. Regul. Integr. Comp. Physiol., v. 281, p. R1232-1242, 2001.

BALDO, B.A.; DANIEL, R.A.; BERRIDGE, C.W.; KELLEY, A.E. Overlapping distributions of orexin/hypocretin- and dopamine-beta-hydroxylase immunoreactive fibers in rat brain regions mediating arousal, motivation, and stress. J. Comp. Neurol., v. 464, p. 220237, 2003.

BARTH, S.W.; RIEDIGER, T.; LUTZ, T.A.; RECHKEMMER, G. Differential effects of amylin and salmon calcitonin on neuropeptide gene expression in the lateral hypothalamic area and the arcuate nucleus of the rat. Neurosci. Lett., v. 341, p. 131-134, 2003.

BASKIN, D.G.; SIPOLS, A.J.; SCHWARTZ, M.W.; WHITE, M.F. Immunocytochemical detection of insulin receptor substrate-1 (IRS-1) in rat brain: colocalization with phosphotyrosine. Regul. Pept., v. 48, p. 257-266, 1993.

BASKIN, D.G.; FIGLEWICZ LATTEMANN, D.; SEELEY, R.J.; WOODS, S.C.; PORTE, D., JR.; SCHWARTZ, M.W. Insulin and leptin: dual adiposity signals to the brain for the regulation of food intake and body weight. Brain Res., v. 848, p. 114-123, 1999a.

BASKIN, D.G.; SCHWARTZ, M.W.; SEELEY, R.J.; WOODS, S.C.; PORTE, D., JR.; BREININGER, J.F.; JONAK, Z.; SCHAEFER, J.; KROUSE, M.; BURGHARDT, C.; CAMPFIELD, L.A.; BURN, P.; KOCHAN, J.P. Leptin receptor long-form splice-variant protein expression in neuron cell bodies of the brain and co-localization with neuropeptide $\mathrm{Y}$ mRNA in the arcuate nucleus. J. Histochem. Cytochem., v. 47, p. 353-362, 1999 b.

BATES, S.H.; STEARNS, W.H.; DUNDON, T.A.; SCHUBERT, M.; TSO, A.W.; WANG, Y.; BANKS, A.S.; LAVERY, H.J.; HAQ, A.K.; MARATOS-FLIER, E.; NEEL, B.G.; SCHWARTZ, M.W.; MYERS, M.G., JR. STAT3 signalling is required for leptin regulation of energy balance but not reproduction. Nature, v. 421, p. 856-859, 2003.

BAYER, V.E.; PICKEL, V.M. Ultrastructural localization of tyrosine hydroxylase in the rat ventral tegmental area: relationship between immunolabeling density and neuronal associations. J. Neurosci., v.10, p. 2996-3013, 1990.

BAYER, V.E.; PICKEL, V.M. GABA-labeled terminals form proportionally more synapses with dopaminergic neurons containing low densities of tyrosine hydroxylaseimmunoreactivity in rat ventral tegmental area. Brain Res., v. 559, p. 44-55, 1991.

BAYER, L.; MAIRET-COELLO, G.; RISOLD, P.Y.; GRIFFOND, B. Orexin/hypocretin neurons: chemical phenotype and possible interactions with melanin-concentrating hormone neurons. Regul. Pept., v. 104, p. 33-39, 2002. 
BEAUMONT, K.; KENNEY, M.A.; YOUNG, A.A.; RINK, T.J. High affinity amylin binding sites in rat brain. Mol. Pharmacol., v. 44, p. 493-497, 1993.

BECKSTEAD, R.M.; DOMESICK, V.B.; NAUTA, W.J. Efferent connections of the substantia nigra and ventral tegmental area in the rat. Brain Res., v. 175, p. 191-217, 1979.

BELLINGER, L.L.; BERNARDIS, L.L.; MENDEL, V.E. Effect of ventromedial and dorsomedial hypothalamic lesions on circadian corticosterone rhythms. Neuroendocrinology, v. 22, p. 216-225, 1976.

BELLINGER, L.L.; BERNARDIS, L.L. The dorsomedial hypothalamic nucleus and its role in ingestive behavior and body weight regulation: lessons learned from lesioning studies. Physiol. Behav., v. 76, p. 431-442, 2002.

BERK, M.L.; FINKELSTEIN, J.A. Afferent projections to the preoptic area and hypothalamic regions in the rat brain. Neuroscience, v. 6, p. 1601-1624, 1981.

BERRIDGE, K.C. Food reward: brain substrates of wanting and liking. Neurosci. Biobehav. Rev., v. 20, p. 1-25, 1996.

BERNARDIS, L.L.; BELLINGER, L.L. The lateral hypothalamic area revisited: ingestive behavior. Neurosci. Biobehav. Rev., v. 20, p. 189-287, 1996.

BERRIDGE, K.C.; ROBINSON, T.E. What is the role of dopamine in reward: hedonic impact, reward learning, or incentive salience? Brain Res. Brain Res. Rev., v. 28, p. 309369, 1998.

BESTER, H.; BESSON, J.M.; BERNARD, J.F. Organization of efferent projections from the parabrachial area to the hypothalamus: a Phaseolus vulgaris-leucoagglutinin study in the rat. J. Comp. Neurol., v. 383, p. 245-281, 1997.

BIELAJEW, C.; SHIZGAL, P. Evidence implicating descending fibers in self-stimulation of the medial forebrain bundle. J. Neurosci., v. 6, p. 919-929, 1986.

BIELAJEW, C.; BUSHNIK, T.; KONKLE, A.T.; SCHINDLER, D. The substrate for brainstimulation reward in the lateral preoptic area. II. Connections to the ventral tegmental area. Brain Res., v. 881, p. 112-120, 2000.

BITTENCOURT, J.C.; PRESSE, F.; ARIAS, C.; PETO, C.; VAUGHAN, J.; NAHON, J.L.; VALE, W.; SAWCHENKO, P.E. The melanin-concentrating hormone system of the rat brain: an immuno- and hybridization histochemical characterization. J. Comp. Neurol., v. 319, p. 218-245, 1992.

BJÖRKLUND, A.; LINDVALL, O. Chapter III: Dopamine-containing systems in the CNS. In: BJÖRKLUND, A.; HÖKFELT, T. (Ed.). Handbook of Chemical Neuroanatomy. Amsterdan: Elsevier Science Publisher, 1984. v. 2, p. 55-122. Classical transmiters in the CNS: Part I.

BJORKLUND, A.; DUNNETT, S.B. Dopamine neuron systems in the brain: an update. 
Trends Neurosci., v. 30, p. 194-202, 2007.

BOLANOS, C.A.; PERROTTI, L.I.; EDWARDS, S.; EISCH, A.J.; BARROT, M.; OLSON, V.G.; RUSSELL, D.S.; NEVE, R.L.; NESTLER, E.J. Phospholipase Cgamma in distinct regions of the ventral tegmental area differentially modulates mood-related behaviors. $\mathbf{J}$. Neurosci., v. 23, p. 7569-7576, 2003.

BOLANOS, C.A.; NEVE, R.L.; NESTLER, E.J. Phospholipase C gamma in distinct regions of the ventral tegmental area differentially regulates morphine-induced locomotor activity. Synapse, v. 56, p. 166-169, 2005.

BOULANT, J.A. Hypothalamic mechanisms in thermoregulation. Fed. Proc., v. 40, p. 2843$2850,1981$.

BRISKI, K.; GILLEN, E. Differential distribution of Fos expression within the male rat preoptic area and hypothalamus in response to physical vs. psychological stress. Brain Res. Bull., v. 55, p. 401-408, 2001.

BROBERGER, C.; DE LECEA, L.; SUTCLIFFE, J.G.; HOKFELT, T. Hypocretin/orexinand melanin-concentrating hormone-expressing cells form distinct populations in the rodent lateral hypothalamus: relationship to the neuropeptide $\mathrm{Y}$ and agouti gene-related protein systems. J. Comp. Neurol., v. 402, p. 460-474, 1998.

BROG, J.S.; SALYAPONGSE, A.; DEUTCH, A.Y.; ZAHM, D.S. The patterns of afferent innervation of the core and shell in the "accumbens" part of the rat ventral striatum: immunohistochemical detection of retrogradely transported fluoro-gold. J. Comp. Neurol., v. 338 , p. $255-278,1993$.

BRUNETTI, L.; RECINELLA, L.; ORLANDO, G.; MICHELOTTO, B.; DI NISIO, C.; VACCA, M. Effects of ghrelin and amylin on dopamine, norepinephrine and serotonin release in the hypothalamus. Eur. J. Pharmacol., v. 454, p. 189-192, 2002.

BRUNING, J.C.; GAUTAM, D.; BURKS, D.J.; GILLETTE, J.; SCHUBERT, M.; ORBAN, P.C.; KLEIN, R.; KRONE, W.; MULLER-WIELAND, D.; KAHN, C.R. Role of brain insulin receptor in control of body weight and reproduction. Science, v. 289, p. 2122-2125, 2000 .

BUBSER, M.; FADEL, J.R.; JACKSON, L.L.; MEADOR-WOODRUFF, J.H.; JING, D.; DEUTCH, A.Y. Dopaminergic regulation of orexin neurons. Eur. J. Neurosci., v. 21, p. 2993-3001, 2005.

BUCCAFUSCO, J.J.; BREZENOFF, H.E. Pharmacological study of a cholinergic mechanism within the rat posterior hypothalamic nucleus which mediates a hypertensive response. Brain Res., v. 165, p. 295-310, 1979.

BUSHNIK, T.; BIELAJEW, C.; KONKLE, A.T. The substrate for brain-stimulation reward in the lateral preoptic area. I. Anatomical mapping of its boundaries. Brain Res., v. 881, p. 103-111, 2000. 
CARR, D.B.; SESACK, S.R. Projections from the rat prefrontal cortex to the ventral tegmental area: target specificity in the synaptic associations with mesoaccumbens and mesocortical neurons. J. Neurosci., v.20, p. 3864-3873, 2000.

CARR, K.D. Feeding, drug abuse, and the sensitization of reward by metabolic need. Neurochem. Res., v. 21, p. 1455-1467, 1996.

CARR, K.D. Augmentation of drug reward by chronic food restriction: behavioral evidence and underlying mechanisms. Physiol. Behav., v. 76, p. 353-364, 2002.

CARRO, E.; PINILLA, L.; SEOANE, L.M.; CONSIDINE, R.V.; AGUILAR, E.; CASANUEVA, F.F.; DIEGUEZ, C. Influence of endogenous leptin tone on the estrous cycle and luteinizing hormone pulsatility in female rats. Neuroendocrinology, v. 66, p. 375-377, 1997.

CHAMBERS, J.; AMES, R.S.; BERGSMA, D.; MUIR, A.; FITZGERALD, L.R.; HERVIEU, G.; DYTKO, G.M.; FOLEY, J.J.; MARTIN, J.; LIU, W.S.; PARK, J.; ELLIS, C.; GANGULY, S.; KONCHAR, S.; CLUDERAY, J.; LESLIE, R.; WILSON, S.; SARAU, H.M. Melanin-concentrating hormone is the cognate ligand for the orphan G-protein-coupled receptor SLC-1. Nature, v. 400, p. 261-265, 1999.

CHANCE, W.T.; BALASUBRAMANIAM, A.; ZHANG, F.S.; WIMALAWANSA, S.J.; FISCHER, J.E. Anorexia following the intrahypothalamic administration of amylin. Brain Res., v. 539, p. 352-354, 1991.

CHANG, H.T.; KITAI, S.T. Projection neurons of the nucleus accumbens: an intracellular labeling study. Brain Res., v. 347, p. 112-116, 1985.

CHAVEZ, M.; KAIYALA, K.; MADDEN, L.J.; SCHWARTZ, M.W.; WOODS, S.C. Intraventricular insulin and the level of maintained body weight in rats. Behav. Neurosci., v. 109, p. 528-531, 1995.

CHIBA, T.; MURATA, Y. Afferent and efferent connections of the medial preoptic area in the rat: a WGA-HRP study. Brain Res. Bull., v. 14, p. 261-272, 1985.

CINTI, S.; FREDERICH, R.C.; ZINGARETTI, M.C.; DE MATTEIS, R.; FLIER, J.S.; LOWELL, B.B. Immunohistochemical localization of leptin and uncoupling protein in white and brown adipose tissue. Endocrinology, v. 138, p. 797-804, 1997.

CONRAD, L.C.; PFAFF, D.W. Autoradiographic tracing of nucleus accumbens efferents in the rat. Brain Res., v. 113, p. 589-596, 1976.

COOLEN, L.M.; PETERS, H.J.; VEENING, J.G. Fos immunoreactivity in the rat brain following consummatory elements of sexual behavior: a sex comparison. Brain Res., v. 738, p. 67-82, 1996.

COWLEY, M.A.; SMART, J.L.; RUBINSTEIN, M.; CERDAN, M.G.; DIANO, S.; HORVATH, T.L.; CONE, R.D.; LOW, M.J. Leptin activates anorexigenic POMC neurons through a neural network in the arcuate nucleus. Nature, v. 411, p. 480-484, 2001. 
COWLEY, M.A.; SMITH, R.G.; DIANO, S.; TSCHOP, M.; PRONCHUK, N.; GROVE, K.L.; STRASBURGER, C.J.; BIDLINGMAIER, M.; ESTERMAN, M.; HEIMAN, M.L.; GARCIA-SEGURA, L.M.; NILLNI, E.A.; MENDEZ, P.; LOW, M.J.; SOTONYI, P.; FRIEDMAN, J.M.; LIU, H.; PINTO, S.; COLMERS, W.F.; CONE, R.D.; HORVATH, T.L. The distribution and mechanism of action of ghrelin in the CNS demonstrates a novel hypothalamic circuit regulating energy homeostasis. Neuron, v. 37, p. 649-661, 2003.

CUMMINGS, D.E.; PURNELL, J.Q.; FRAYO, R.S.; SCHMIDOVA, K.; WISSE, B.E.; WEIGLE, D.S. A preprandial rise in plasma ghrelin levels suggests a role in meal initiation in humans. Diabetes, v. 50, p. 1714-1719, 2001.

CUMMINGS, D.E.; WEIGLE, D.S.; FRAYO, R.S.; BREEN, P.A.; MA, M.K.; DELLINGER, E.P.; PURNELL, J.Q. Plasma ghrelin levels after diet-induced weight loss or gastric bypass surgery. N. Engl. J. Med., v. 346, p. 1623-1630, 2002.

CUMMINGS, D.E.; FRAYO, R.S.; MARMONIER, C.; AUBERT, R.; CHAPELOT, D. Plasma ghrelin levels and hunger scores in humans initiating meals voluntarily without timeand food-related cues. Am. J. Physiol. Endocrinol. Metab., v. 287, p. E297-304, 2004.

CUNNINGHAM, M.J.; CLIFTON, D.K.; STEINER, R.A. Leptin's actions on the reproductive axis: perspectives and mechanisms. Biol. Reprod., v. 60, p. 216-222, 1999.

CUTLER, D.J.; MORRIS, R.; SHERIDHAR, V.; WATTAM, T.A.; HOLMES, S.; PATEL, S.; ARCH, J.R.; WILSON, S.; BUCKINGHAM, R.E.; EVANS, M.L.; LESLIE, R.A.; WILLIAMS, G. Differential distribution of orexin-A and orexin-B immunoreactivity in the rat brain and spinal cord. Peptides, v. 20, p. 1455-1470, 1999.

DAHLSTROM, A.; FUXE, K. Evidence for the Existence of Monoamine-Containing Neurons in the Central Nervous System. I. Demonstration of Monoamines in the Cell Bodies of Brain Stem Neurons. Acta Physiol. Scand. Suppl., v. p. SUPPL 232:231-255, 1964.

DATE, Y.; UETA, Y.; YAMASHITA, H.; YAMAGUCHI, H.; MATSUKURA, S.; KANGAWA, K.; SAKURAI, T.; YANAGISAWA, M.; NAKAZATO, M. Orexins, orexigenic hypothalamic peptides, interact with autonomic, neuroendocrine and neuroregulatory systems. Proc. Natl. Acad. Sci. USA, v. 96, p. 748-753, 1999.

DE ARAUJO, I.E.; OLIVEIRA-MAIA, A.J.; SOTNIKOVA, T.D.; GAINETDINOV, R.R.; CARON, M.G.; NICOLELIS, M.A.; SIMON, S.A. Food reward in the absence of taste receptor signaling. Neuron, v. 57, p. 930-941, 2008.

DEL-FAVA, F. Estudo das conexões eferentes dos núcleos rostral linear da rafe e interfascicular no rato. 2006. Tese (Doutorado) - Depto de Fisiologia e Biofísica do Instituto de Ciências Biomédicas, Universidade de São Paulo, São Paulo, 2007.

DEL-FAVA, F.; HASUE, R.H.; FERREIRA, J.G.; SHAMMAH-LAGNADO, S.J. Efferent connections of the rostral linear nucleus of the ventral tegmental area in the rat. Neuroscience, v. 145, p. 1059-1076, 2007. 
DEL-FAVA, F.; HASUE, R.H.; SHAMMAH-LAGNADO, S.J. Conexões eferentes do núcleo rostral linear da rafe no rato. In: FESBE 2005, 24 ago. 2005, Águas de Lindóia - SP. Resumos... Setor: Neuromorfologia.

DEL-FAVA, F.; HASUE, R.H.; SHAMMAH-LAGNADO, S.J. Conexões eferentes do núcleo interfascicular da área tegmental ventral no rato. In: FESBE 2006, 23 ago. 2006, Águas de Lindóia - SP. Resumos... Setor: Neuromorfologia.

DE LECEA, L.; KILDUFF, T.S.; PEYRON, C.; GAO, X.; FOYE, P.E.; DANIELSON, P.E.; FUKUHARA, C.; BATTENBERG, E.L.; GAUTVIK, V.T.; BARTLETT, F.S., 2ND; FRANKEL, W.N.; VAN DEN POL, A.N.; BLOOM, F.E.; GAUTVIK, K.M.; SUTCLIFFE, J.G. The hypocretins: hypothalamus-specific peptides with neuroexcitatory activity. Proc. Natl. Acad. Sci. USA, v. 95, p. 322-327, 1998.

DELFS, J.M.; KELLEY, A.E. The role of D1 and D2 dopamine receptors in oral stereotypy induced by dopaminergic stimulation of the ventrolateral striatum. Neuroscience, v. 39, p. 59-67, 1990.

DEUTCH, A.Y.; GOLDSTEIN, M.; BALDINO, F. JR.; ROTH, R.H. Telencephalic projections of the A8 dopamine cell group. Ann. N.Y. Acad. Sci., v.537, p. 27-50, 1988.

DICKSON, P.R.; LANG, C.G.; HINTON, S.C.; KELLEY, A.E. Oral stereotypy induced by amphetamine microinjection into striatum: an anatomical mapping study. Neuroscience, v. 61, p. 81-91, 1994.

DIMICCO, J.A.; ABSHIRE, V.M.; HANKINS, K.D.; SAMPLE, R.H.; WIBLE, J.H., JR. Microinjection of GABA antagonists into posterior hypothalamus elevates heart rate in anesthetized rats. Neuropharmacology, v. 25, p. 1063-1066, 1986.

DONG, H.W.; SWANSON, L.W. Projections from the rhomboid nucleus of the bed nuclei of the stria terminalis: implications for cerebral hemisphere regulation of ingestive behaviors. J. Comp. Neurol., v. 463, p. 434-472, 2003.

DONG, H.W.; SWANSON, L.W. Projections from bed nuclei of the stria terminalis, dorsomedial nucleus: implications for cerebral hemisphere integration of neuroendocrine, autonomic, and drinking responses. J. Comp. Neurol., v. 494, p. 75-107, 2006 a.

DONG, H.W.; SWANSON, L.W. Projections from bed nuclei of the stria terminalis, magnocellular nucleus: implications for cerebral hemisphere regulation of micturition, defecation, and penile erection. J. Comp. Neurol., v. 494, p. 108-141, 2006 b.

DONG, H.W.; SWANSON, L.W. Projections from bed nuclei of the stria terminalis, anteromedial area: cerebral hemisphere integration of neuroendocrine, autonomic, and behavioral aspects of energy balance. J. Comp. Neurol., v. 494, p. 142-178, 2006c.

DUVA, M.A.; TOMKINS, E.M.; MORANDA, L.M.; KAPLAN, R.; SUKHASEUM, A.; JIMENEZ, A.; STANLEY, B.G. Reverse microdialysis of N-methyl-D-aspartic acid into the lateral hypothalamus of rats: effects on feeding and other behaviors. Brain Res., v. 921, p. 122-132, 2001. 
DUVA, M.A.; TOMKINS, E.M.; MORANDA, L.M.; KAPLAN, R.; SUKHASEUM, A.; BERNARDO, J.P.; STANLEY, B.G. Regional differences in feeding and other behaviors elicited by $\mathrm{N}$-methyl-D-aspartic acid in the rodent hypothalamus: a reverse microdialysis mapping study. Brain Res., v. 925, p. 141-147, 2002.

DUVA, M.A.; TOMKINS, E.M.; MORANDA, L.M.; KAPLAN, R.; SUKHASEUM, A.; STANLEY, B.G. Origins of lateral hypothalamic afferents associated with N-methyl-daspartic acid-elicited eating studied using reverse microdialysis of NMDA and Fluorogold. Neurosci. Res., v. 52, p. 95-106, 2005.

ELIAS, C.F.; SAPER, C.B.; MARATOS-FLIER, E.; TRITOS, N.A.; LEE, C.; KELLY, J.; TATRO, J.B.; HOFFMAN, G.E.; OLLMANN, M.M.; BARSH, G.S.; SAKURAI, T.; YANAGISAWA, M.; ELMQUIST, J.K. Chemically defined projections linking the mediobasal hypothalamus and the lateral hypothalamic area. J. Comp. Neurol., v. 402, p. 442-459, 1998.

ELIAS, C.F.; KELLY, J.F.; LEE, C.E.; AHIMA, R.S.; DRUCKER, D.J.; SAPER, C.B.; ELMQUIST, J.K. Chemical characterization of leptin-activated neurons in the rat brain. J. Comp. Neurol., v. 423, p. 261-281, 2000.

ELIAS, C.F.; LEE, C.E.; KELLY, J.F.; AHIMA, R.S.; KUHAR, M.; SAPER, C.B.; ELMQUIST, J.K. Characterization of CART neurons in the rat and human hypothalamus. J. Comp. Neurol., v. 432, p. 1-19, 2001.

ELMQUIST, J.K.; SCAMMELL, T.E.; JACOBSON, C.D.; SAPER, C.B. Distribution of Fos-like immunoreactivity in the rat brain following intravenous lipopolysaccharide administration. J. Comp. Neurol., v. 371, p. 85-103, 1996.

ELMQUIST, J.K.; AHIMA, R.S.; MARATOS-FLIER, E.; FLIER, J.S.; SAPER, C.B. Leptin activates neurons in ventrobasal hypothalamus and brainstem. Endocrinology, v. 138, p. 839-842, 1997.

ELMQUIST, J.K.; BJORBAEK, C.; AHIMA, R.S.; FLIER, J.S.; SAPER, C.B. Distributions of leptin receptor mRNA isoforms in the rat brain. J. Comp. Neurol., v. 395, p. 535-547, 1998.

ETGEN, A.M.; CHU, H.P.; FIBER, J.M.; KARKANIAS, G.B.; MORALES, J.M. Hormonal integration of neurochemical and sensory signals governing female reproductive behavior. Behav. Brain Res., v. 105, p. 93-103, 1999.

FADEL, J.; DEUTCH, A.Y. Anatomical substrates of orexin-dopamine interactions: lateral hypothalamic projections to the ventral tegmental area. Neuroscience, v. 111, p. 379-387, 2002.

FALLON, J.H.; KOZIELL, D.A.; MOORE, R.Y. Catecholamine innervation of the basal forebrain. II. Amygdala, suprarhinal cortex and entorhinal cortex. J. Comp. Neurol., v. 180, p. 509-532, 1978.

FALLON, J.H.; MOORE, R.Y. Catecholamine innervation of the basal forebrain. IV. Topography of the dopamine projection to the basal forebrain and neostriatum. J. Comp. 
Neurol., v. 180, p. 545-580, 1978.

FANTIN, V.R.; WANG, Q.; LIENHARD, G.E.; KELLER, S.R. Mice lacking insulin receptor substrate 4 exhibit mild defects in growth, reproduction, and glucose homeostasis. Am. J. Physiol. Endocrinol. Metab., v. 278, p. E127-133, 2000.

FERREIRA, J.G.; DEL FAVA, F.; HASUE, R.H.; SHAMMAH-LAGNADO, S.J. Organization of ventral tegmental area projections to the ventral tegmental area-nigral complex in the rat. Neuroscience, v. 153, p. 196-213, 2008.

FIELDS, H.L.; HJELMSTAD, G.O.; MARGOLIS, E.B.; NICOLA, S.M. Ventral tegmental area neurons in learned appetitive behavior and positive reinforcement. Annu. Rev. Neurosci., v.30, p. 289-316, 2007.

FIGLEWICZ, D.P.; SZOT, P.; CHAVEZ, M.; WOODS, S.C.; VEITH, R.C. Intraventricular insulin increases dopamine transporter mRNA in rat VTA/substantia nigra. Brain Res., v. 644, p. 331-334, 1994.

FIGLEWICZ, D.P.; BROT, M.D.; MCCALL, A.L.; SZOT, P. Diabetes causes differential changes in CNS noradrenergic and dopaminergic neurons in the rat: a molecular study. Brain Res., v. 736, p. 54-60, 1996.

FIGLEWICZ, D.P.; PATTERSON, T.A.; ZAVOSH, A.; BROT, M.D.; ROITMAN, M.; SZOT, P. Neurotransmitter transporters: target for endocrine regulation. Horm. Metab. Res., v. 31, p. 335-339, 1999.

FIGLEWICZ, D.P.; HIGGINS, M.S.; NG-EVANS, S.B.; HAVEL, P.J. Leptin reverses sucrose-conditioned place preference in food-restricted rats. Physiol. Behav., v. 73, p. 229234, 2001.

FIGLEWICZ, D.P. Adiposity signals and food reward: expanding the CNS roles of insulin and leptin. Am. J. Physiol. Regul. Integr. Comp. Physiol., v. 284, p. R882-892, 2003a.

FIGLEWICZ, D.P. Insulin, food intake, and reward. Semin. Clin. Neuropsychiatry, v. 8, p. 82-93, $2003 \mathrm{~b}$.

FIGLEWICZ, D.P.; EVANS, S.B.; MURPHY, J.; HOEN, M.; BASKIN, D.G. Expression of receptors for insulin and leptin in the ventral tegmental area/substantia nigra (VTA/SN) of the rat. Brain Res., v. 964, p. 107-115, 2003.

FIGLEWICZ, D.P.; BENNETT, J.; EVANS, S.B.; KAIYALA, K.; SIPOLS, A.J.; BENOIT, S.C. Intraventricular insulin and leptin reverse place preference conditioned with high-fat diet in rats. Behav. Neurosci., v. 118, p. 479-487, 2004.

FIGLEWICZ, D.P.; BENNETT, J.L.; NALEID, A.M.; DAVIS, C.; GRIMM, J.W. Intraventricular insulin and leptin decrease sucrose self-administration in rats. Physiol. Behav., v. 89, p. 611-616, 2006.

FIGLEWICZ, D.P.; MACDONALD NALEID, A.; SIPOLS, A.J. Modulation of food reward 
by adiposity signals. Physiol. Behav., v. 91, p. 473-478, 2007.

FOLLI, F.; BONFANTI, L.; RENARD, E.; KAHN, C.R.; MERIGHI, A. Insulin receptor substrate-1 (IRS-1) distribution in the rat central nervous system. J. Neurosci., v. 14, p. 6412-6422, 1994.

FULTON, S.; WOODSIDE, B.; SHIZGAL, P. Modulation of brain reward circuitry by leptin. Science, v. 287, p. 125-128, 2000.

FULTON, S.; PISSIOS, P.; MANCHON, R.P.; STILES, L.; FRANK, L.; POTHOS, E.N.; MARATOS-FLIER, E.; FLIER, J.S. Leptin regulation of the mesoaccumbens dopamine pathway. Neuron, v. 51, p. 811-822, 2006.

GALLO, R.V. Effect of electrical stimulation of the dorsomedial hypothalamic nucleus on pulsatile LH release in ovariectomized rats. Neuroendocrinology, v. 32, p. 134-138, 1981.

GARCIA, B.G.; WEI, Y.; MORON, J.A.; LIN, R.Z.; JAVITCH, J.A.; GALLI, A. Akt is essential for insulin modulation of amphetamine-induced human dopamine transporter cellsurface redistribution. Mol. Pharmacol., v. 68, p. 102-109, 2005.

GEISLER, S.; ZAHM, D.S. Afferents of the ventral tegmental area in the rat-anatomical substratum for integrative functions. J. Comp. Neurol., v. 490, p. 270-294, 2005.

GEISLER, S.; MARINELLI, M.; DEGARMO, B.; BECKER, M.L.; FREIMAN, A.J.; BEALES, M.; MEREDITH, G.E.; ZAHM, D.S. Prominent activation of brainstem and pallidal afferents of the ventral tegmental area by cocaine. Neuropsychopharmacology, v. 33, p. 2688-2700, 2007.

GERFEN, C.R.; BAIMBRIDGE, K.G.; THIBAULT, J. The neostriatal mosaic: III. Biochemical and developmental dissociation of patch-matrix mesostriatal systems. J. Neurosci., v. 7, p. 3935-3944, 1987b.

GERFEN, C.R.; HERKENHAM, M.; THIBAULT, J. The neostriatal mosaic: II. Patch- and matrix-directed mesostriatal dopaminergic and non-dopaminergic systems. J. Neurosci., v. 7, p. 3915-3934, 1987a.

GOLDMAN-RAKIC, P.S. The "psychic" neuron of the cerebral cortex. Ann. N.Y. Acad. Sci., v.868, p. 13-26, 1999.

GOLDMAN-RAKIC, P.S.; CASTNER, S.A.; SVENSSON, T.H.; SIEVER, L.J.; WILLIAMS, G.V. Targeting the dopamine D1 receptor in schizophrenia: insights for cognitive dysfunction. Psychopharmacology, v.174, p. 3-16, 2004.

GOOLEY, J.J.; SCHOMER, A.; SAPER, C.B. The dorsomedial hypothalamic nucleus is critical for the expression of food-entrainable circadian rhythms. Nat. Neurosci., v. 9, p. 398407, 2006.

GOREN, H.J.; KULKARNI, R.N.; KAHN, C.R. Glucose homeostasis and tissue transcript 
content of insulin signaling intermediates in four inbred strains of mice: C57BL/6, C57BLKS/6, DBA/2, and 129X1. Endocrinology, v. 145, p. 3307-3323, 2004.

GOTO, M.; CANTERAS, N.S.; BURNS, G.; SWANSON, L.W. Projections from the subfornical region of the lateral hypothalamic area. J. Comp. Neurol., v. 493, p. 412-438, 2005 .

GRACE, A.A.; BUNNEY, B.S. Intracellular and extracellular electrophysiology of nigral dopaminergic neurons -3. Evidence for electrotonic coupling. Neuroscience, v.10, p.333-348, 1983.

GRIFFOND, B.; DERAY, A.; FELLMANN, D.; CIOFI, P.; CROIX, D.; BUGNON, C. Colocalization of prolactin- and dynorphin-like substances in a neuronal population of the rat lateral hypothalamus. Neurosci. Lett., v. 156, p. 91-95, 1993.

GRIFFOND, B.; GRILLON, S.; DUVAL, J.; COLARD, C.; JACQUEMARD, C.; DERAY, A.; FELLMANN, D. Occurrence of secretogranin II in the prolactin-immunoreactive neurons of the rat lateral hypothalamus: an in situ hybridization and immunocytochemical study. $\mathbf{J}$. Chem. Neuroanat., v. 9, p. 113-119, 1995.

GROENEWEGEN, H.J.; RUSSCHEN, F.T. Organization of the efferent projections of the nucleus accumbens to pallidal, hypothalamic, and mesencephalic structures: a tracing and immunohistochemical study in the cat. J. Comp. Neurol., v. 223, p. 347-367, 1984.

GROENEWEGEN, H.J.; BERENDSE, H.W.; HABER, S.N. Organization of the output of the ventral striatopallidal system in the rat: ventral pallidal efferents. Neuroscience, v. 57, p. 113-142, 1993.

GUAN, X.M.; YU, H.; PALYHA, O.C.; MCKEE, K.K.; FEIGHNER, S.D.; SIRINATHSINGHJI, D.J.; SMITH, R.G.; VAN DER PLOEG, L.H.; HOWARD, A.D. Distribution of mRNA encoding the growth hormone secretagogue receptor in brain and peripheral tissues. Brain Res. Mol. Brain Res., v. 48, p. 23-29, 1997.

GUNNET, J.W.; FREEMAN, M.E. The interaction of the medial preoptic area and the dorsomedial-ventromedial nuclei of the hypothalamus in the regulation of the mating-induced release of prolactin. Neuroendocrinology, v. 40, p. 232-237, 1985.

GVILIA, I.; XU, F.; MCGINTY, D.; SZYMUSIAK, R. Homeostatic regulation of sleep: a role for preoptic area neurons. J. Neurosci., v. 26, p. 9426-9433, 2006.

HABER, S.N.; FUDGE, J.L.; MCFARLAND, N.R. Striatonigrostriatal pathways in primates form an ascending spiral from the shell to the dorsolateral striatum. J. Neurosci., v. 20, p. 2369-2382, 2000.

HAGAN, J.J.; LESLIE, R.A.; PATEL, S.; EVANS, M.L.; WATTAM, T.A.; HOLMES, S.; BENHAM, C.D.; TAYLOR, S.G.; ROUTLEDGE, C.; HEMMATI, P.; MUNTON, R.P.; ASHMEADE, T.E.; SHAH, A.S.; HATCHER, J.P.; HATCHER, P.D.; JONES, D.N.; SMITH, M.I.; PIPER, D.C.; HUNTER, A.J.; PORTER, R.A.; UPTON, N. Orexin A activates locus coeruleus cell firing and increases arousal in the rat. Proc. Natl. Acad. Sci. USA, v. 96, 
p. 10911-10916, 1999.

HAJNAL, A.; NORGREN, R. Accumbens dopamine mechanisms in sucrose intake. Brain Res., v. 904, p. 76-84, 2001.

HAJNAL, A.; SMITH, G.P.; NORGREN, R. Oral sucrose stimulation increases accumbens dopamine in the rat. Am. J. Physiol. Regul. Integr. Comp. Physiol., v. 286, p. R31-37, 2004.

HALLIDAY, G.M.; TORK, I. Comparative anatomy of the ventromedial mesencephalic tegmentum in the rat, cat, monkey and human. J. Comp. Neurol., v. 252, p. 423-445, 1986.

HASUE, R.H. Conexões eferentes do núcleo caudal linear da rafe: um estudo com a técnica da leucoaglutinina do Phaseolus vulgaris (PHA-L) no rato. 2004. Tese (Doutorado) - Depto de Fisiologia e Biofísica do Instituto de Ciências Biomédicas, Universidade de São Paulo, São Paulo, 2004.

HASUE, R.H.; DEL FAVA, F.; SHAMMAH-LAGNADO, S.J. Conexões eferentes do núcleo caudal linear da rafe no rato. In: FESBE 2005, 24 ago. 2005, Águas de Lindóia - SP. Resumos... Setor: Neuromorfologia.

HASUE, R.H.; SHAMMAH-LAGNADO, S.J. Origin of the dopaminergic innervation of the central extended amygdala and accumbens shell: a combined retrograde tracing and immunohistochemical study in the rat. J. Comp. Neurol., v. 454, p. 15-33, 2002.

HAVRANKOVA, J.; ROTH, J.; BROWNSTEIN, M. Insulin receptors are widely distributed in the central nervous system of the rat. Nature, v. 272, p. 827-829, 1978.

HAWES, B.E.; KIL, E.; GREEN, B.; O'NEILL, K.; FRIED, S.; GRAZIANO, M.P. The melanin-concentrating hormone receptor couples to multiple $G$ proteins to activate diverse intracellular signaling pathways. Endocrinology, v. 141, p. 4524-4532, 2000.

HERBERT, H.; MOGA, M.M.; SAPER, C.B. Connections of the parabrachial nucleus with the nucleus of the solitary tract and the medullary reticular formation in the rat. J. Comp. Neurol., v. 293, p. 540-580, 1990.

HETHERINGTON, A.; RANSON, S. Hypothalamic lesions and adiposity in the rat. Anat. Rec., v. 78, p. 149-172, 1940.

HOMMEL, J.D.; TRINKO, R.; SEARS, R.M.; GEORGESCU, D.; LIU, Z.W.; GAO, X.B.; THURMON, J.J.; MARINELLI, M.; DILEONE, R.J. Leptin receptor signaling in midbrain dopamine neurons regulates feeding. Neuron, v. 51, p. 801-810, 2006.

HORSCH, D.; KAHN, C.R. Region-specific mRNA expression of phosphatidylinositol 3kinase regulatory isoforms in the central nervous system of C57BL/6J mice. J. Comp. Neurol., v. 415, p. 105-120, 1999.

HORVATH, T.L.; DIANO, S.; SOTONYI, P.; HEIMAN, M.; TSCHOP, M. Minireview: ghrelin and the regulation of energy balance--a hypothalamic perspective. Endocrinology, v. 
142, p. 4163-4169, 2001.

HUR, E.E.; ZABORSZKY, L. Vglut2 afferents to the medial prefrontal and primary somatosensory cortices: a combined retrograde tracing in situ hybridization. J. Comp. Neurol., v. 483, p. 351-373, 2005.

IDA, T.; NAKAHARA, K.; KATAYAMA, T.; MURAKAMI, N.; NAKAZATO, M. Effect of lateral cerebroventricular injection of the appetite-stimulating neuropeptide, orexin and neuropeptide Y, on the various behavioral activities of rats. Brain Res., v. 821, p. 526-529, 1999.

IKEMOTO, S.; MURPHY, J.M.; MCBRIDE, W.J. Regional differences within the rat ventral tegmental area for muscimol self-infusions. Pharmacol. Biochem. Behav., v. 61, p. 87-92, 1998.

IKEMOTO, S. Dopamine reward circuitry: two projection systems from the ventral midbrain to the nucleus accumbens-olfactory tubercle complex. Brain Res. Rev., v. 56, p. 27-78, 2007.

INGLEFIELD, J.R.; SCHWARZKOPF, S.B.; KELLOGG, C.K. Alterations in behavioral responses to stressors following excitotoxin lesions of dorsomedial hypothalamic regions. Brain Res., v. 633, p. 151-161, 1994.

INIGUEZ, S.D.; WARREN, B.L.; NEVE, R.L.; NESTLER, E.J.; RUSSO, S.J.; BOLANOSGUZMAN, C.A. Insulin receptor substrate-2 in the ventral tegmental area regulates behavioral responses to cocaine. Behav. Neurosci., v. 122, p. 1172-1177, 2008.

ISHIWATA, T.; HASEGAWA, H.; YASUMATSU, M.; AKANO, F.; YAZAWA, T.; OTOKAWA, M.; AIHARA, Y. The role of preoptic area and anterior hypothalamus and median raphe nucleus on thermoregulatory system in freely moving rats. Neurosci. Lett., v. 306, p. 126-128, 2001.

ITOH, K.; KONISHI, A.; NOMURA, S.; MIZUNO, N.; NAKAMURA, Y.; SUGIMOTO, T. Application of coupled oxidation reaction to electron microscopic demonstration of horseradish peroxidase: cobalt-glucose oxidase method. Brain Res., v. 175, p. 341-346, 1979.

JACOBOWITZ, D.M.; PALKOVITS, M. Topographic atlas of catecholamine and acetylcholinesterase-containing neurons in the rat brain. I. Forebrain (telencephalon, diencephalon). J. Comp. Neurol., v. 157, p. 13-28, 1974.

JANAS, J.D.; STELLAR, J.R. Effects of knife-cut lesions of the medial forebrain bundle in self-stimulating rats. Behav. Neurosci., v. 101, p. 832-845, 1987.

JERLHAG, E.; EGECIOGLU, E.; DICKSON, S.L.; ANDERSSON, M.; SVENSSON, L.; ENGEL, J.A. Ghrelin stimulates locomotor activity and accumbal dopamine-overflow via central cholinergic systems in mice: implications for its involvement in brain reward. Addict Biol., v. 11, p. 45-54, 2006.

JHA, S.K.; ISLAM, F.; MALLICK, B.N. GABA exerts opposite influence on warm and cold sensitive neurons in medial preoptic area in rats. J. Neurobiol., v. 48, p. 291-300, 2001. 
JOHNSON, S.W.; NORTH, R.A. Opioids excite dopamine neurons by hyperpolarization of local interneurons. J. Neurosci., v. 12, p. 483-488, 1992.

KALIVAS, P.W.; BOURDELAIS, A.; ABHOLD, R.; ABBOTT, L. Somatodendritic release of endogenous dopamine: in vivo dialysis in the A10 dopamine region. Neurosci. Lett., v. 100, p. 215-220, 1989.

KALRA, S.P.; DUBE, M.G.; PU, S.; XU, B.; HORVATH, T.L.; KALRA, P.S. Interacting appetite-regulating pathways in the hypothalamic regulation of body weight. Endocr. Rev., v. 20, p. 68-100, 1999.

KATAYAMA, M.; NOGAMI, H.; NISHIYAMA, J.; KAWASE, T.; KAWAMURA, K. Developmentally and regionally regulated expression of growth hormone secretagogue receptor mRNA in rat brain and pituitary gland. Neuroendocrinology, v. 72, p. 333-340, 2000.

KAWAUCHI, H.; KAWAZOE, I.; TSUBOKAWA, M.; KISHIDA, M.; BAKER, B.I. Characterization of melanin-concentrating hormone in chum salmon pituitaries. Nature, v. 305, p. 321-323, 1983.

KELLEY, A.E.; LANG, C.G.; GAUTHIER, A.M. Induction of oral stereotypy following amphetamine microinjection into a discrete subregion of the striatum. Psychopharmacology (Berl.), v. 95, p. 556-559, 1988.

KEIM, S.R.; SHEKHAR, A. The effects of GABAA receptor blockade in the dorsomedial hypothalamic nucleus on corticotrophin (ACTH) and corticosterone secretion in male rats. Brain Res., v. 739, p. 46-51, 1996.

KHAN, A.M.; CURRAS, M.C.; DAO, J.; JAMAL, F.A.; TURKOWSKI, C.A.; GOEL, R.K.; GILLARD, E.R.; WOLFSOHN, S.D.; STANLEY, B.G. Lateral hypothalamic NMDA receptor subunits NR2A and/or NR2B mediate eating: immunochemical/behavioral evidence. Am. J. Physiol., v. 276, p. R880-891, 1999.

KIDO, Y.; BURKS, D.J.; WITHERS, D.; BRUNING, J.C.; KAHN, C.R.; WHITE, M.F.; ACCILI, D. Tissue-specific insulin resistance in mice with mutations in the insulin receptor, IRS-1, and IRS-2. J. Clin. Invest., v. 105, p. 199-205, 2000.

KITA, H.; OOMURA, Y. An anterograde HRP study of retinal projections to the hypothalamus in the rat. Brain Res. Bull., v. 8, p. 249-253, 1982.

KITAMURA, T.; KAHN, C.R.; ACCILI, D. Insulin receptor knockout mice. Annu. Rev. Physiol., v. 65, p. 313-332, 2003.

KLITENICK, M.A.; DEUTCH, A.Y.; CHURCHILL, L.; KALIVAS, P.W. Topography and functional role of dopaminergic projections from the ventral mesencephalic tegmentum to the ventral pallidum. Neuroscience, v. 50, p. 371-386, 1992.

KOBELT, P.; PAULITSCH, S.; GOEBEL, M.; STENGEL, A.; SCHMIDTMANN, M.; VAN DER VOORT, I.R.; TEBBE, J.J.; VEH, R.W.; KLAPP, B.F.; WIEDENMANN, B.; TACHE, 
Y.; MONNIKES, H. Peripheral injection of CCK-8S induces Fos expression in the dorsomedial hypothalamic nucleus in rats. Brain Res., v. 1117, p. 109-117, 2006.

KOBELT, P.; WISSER, A.S.; STENGEL, A.; GOEBEL, M.; INHOFF, T.; NOETZEL, S.; VEH, R.W.; BANNERT, N.; VAN DER VOORT, I.; WIEDENMANN, B.; KLAPP, B.F.; TACHE, Y.; MONNIKES, H. Peripheral injection of ghrelin induces Fos expression in the dorsomedial hypothalamic nucleus in rats. Brain Res., v. 1204, p. 77-86, 2008.

KOJIMA, M.; HOSODA, H.; DATE, Y.; NAKAZATO, M.; MATSUO, H.; KANGAWA, K. Ghrelin is a growth-hormone-releasing acylated peptide from stomach. Nature, v. 402, p. 656-660, 1999.

KORBONITS, M.; GROSSMAN, A.B. Ghrelin: update on a novel hormonal system. Eur. J. Endocrinol., v. 151 Suppl 1, p. S67-70, 2004.

KOROTKOVA, T.M.; BROWN, R.E.; SERGEEVA, O.A.; PONOMARENKO, A.A.; HAAS, H.L. Effects of arousal- and feeding-related neuropeptides on dopaminergic and GABAergic neurons in the ventral tegmental area of the rat. Eur. J. Neurosci., v. 23, p. 2677-2685, 2006.

KOWSKI, A.B.; GEISLER, S.; KRAUSS, M.; VEH, R.W. Differential projections from subfields in the lateral preoptic area to the lateral habenular complex of the rat. J. Comp. Neurol., v. 507, p. 1465-1478, 2008.

KRUGEL, U.; SCHRAFT, T.; KITTNER, H.; KIESS, W.; ILLES, P. Basal and feedingevoked dopamine release in the rat nucleus accumbens is depressed by leptin. Eur. J. Pharmacol., v. 482, p. 185-187, 2003.

LAMMEL, S.; HETZEL, A.; HACKEL, O.; JONES, I.; LISS, B.; ROEPER, J. Unique properties of mesoprefrontal neurons within a dual mesocorticolimbic dopamine system. Neuron, v. 57, p. 760-773, 2008.

LEIBOWITZ, S.F.; ROSSAKIS, C. Pharmacological characterization of perifornical hypothalamic dopamine receptors mediating feeding inhibition in the rat. Brain Res., v. 172, p. $115-130,1979$.

LEIBOWITZ, S.F.; BROWN, L.L. Histochemical and pharmacological analysis of catecholaminergic projections to the perifornical hypothalamus in relation to feeding inhibition. Brain Res., v. 201, p. 315-345, 1980.

LEMBO, P.M.; GRAZZINI, E.; CAO, J.; HUBATSCH, D.A.; PELLETIER, M.; HOFFERT, C.; ST-ONGE, S.; POU, C.; LABRECQUE, J.; GROBLEWSKI, T.; O'DONNELL, D.; PAYZA, K.; AHMAD, S.; WALKER, P. The receptor for the orexigenic peptide melaninconcentrating hormone is a G-protein-coupled receptor. Nat. Cell Biol., v. 1, p. 267-271, 1999.

LEVIN, B.E. Glucose-regulated dopamine release from substantia nigra neurons. Brain Res., v. 874 , p. $158-164,2000$.

LIN, J.S.; SAKAI, K.; VANNI-MERCIER, G.; JOUVET, M. A critical role of the posterior 
hypothalamus in the mechanisms of wakefulness determined by microinjection of muscimol in freely moving cats. Brain Res., v. 479, p. 225-240, 1989.

LOEWY, A.D.; WALLACH, J.H.; MCKELLAR, S. Efferent connections of the ventral medulla oblongata in the rat. Brain Res., v. 228, p. 63-80, 1981.

LUDWIG, D.S.; TRITOS, N.A.; MASTAITIS, J.W.; KULKARNI, R.; KOKKOTOU, E.; ELMQUIST, J.; LOWELL, B.; FLIER, J.S.; MARATOS-FLIER, E. Melanin-concentrating hormone overexpression in transgenic mice leads to obesity and insulin resistance. J. Clin. Invest., v. 107, p. 379-386, 2001.

LUTZ, T.A.; GEARY, N.; SZABADY, M.M.; DEL PRETE, E.; SCHARRER, E. Amylin decreases meal size in rats. Physiol. Behav., v. 58, p. 1197-1202, 1995.

LUTZ, T.A.; TSCHUDY, S.; MOLLET, A.; GEARY, N.; SCHARRER, E. Dopamine D(2) receptors mediate amylin's acute satiety effect. Am. J. Physiol. Regul. Integr. Comp. Physiol., v. 280, p. R1697-1703, 2001.

MANSOUR, A.; MEADOR-WOODRUFF, J.H.; BUNZOW, J.R.; CIVELLI, O.; AKIL, H.; WATSON, S.J. Localization of dopamine D2 receptor mRNA and D1 and D2 receptor binding in the rat brain and pituitary: an in situ hybridization-receptor autoradiographic analysis. J. Neurosci., v. 10, p. 2587-2600, 1990.

MARCUS, J.N.; ASCHKENASI, C.J.; LEE, C.E.; CHEMELLI, R.M.; SAPER, C.B.; YANAGISAWA, M.; ELMQUIST, J.K. Differential expression of orexin receptors 1 and 2 in the rat brain. J. Comp. Neurol., v. 435, p. 6-25, 2001.

MARGOLIS, R.U.; ALTSZULER, N. Insulin in the cerebrospinal fluid. Nature, v. 215, p. 1375-1376, 1967.

MARTIN, J.R.; BEINFELD, M.C.; WESTFALL, T.C. Blood pressure increases after injection of neuropeptide Y into posterior hypothalamic nucleus. Am. J. Physiol., v. 254, p. H879-888, 1988.

MASUZAKI, H.; OGAWA, Y.; SAGAWA, N.; HOSODA, K.; MATSUMOTO, T.; MISE, H.; NISHIMURA, H.; YOSHIMASA, Y.; TANAKA, I.; MORI, T.; NAKAO, K. Nonadipose tissue production of leptin: leptin as a novel placenta-derived hormone in humans. Nat. Med., v. 3, p. 1029-1033, 1997.

MCCARTHY, H.D.; KILPATRICK, A.P.; TRAYHURN, P.; WILLIAMS, G. Widespread increases in regional hypothalamic neuropeptide $\mathrm{Y}$ levels in acute cold-exposed rats. Neuroscience, v. 54, p. 127-132, 1993.

MENENDEZ, J.A.; ATRENS, D.M. Insulin increases energy expenditure and respiratory quotient in the rat. Pharmacol. Biochem. Behav., v. 34, p. 765-768, 1989.

MENENDEZ, J.A.; ATRENS, D.M. Insulin and the paraventricular hypothalamus: modulation of energy balance. Brain Res., v. 555, p. 193-201, 1991.

MILLER, S.M.; LONSTEIN, J.S. Dopaminergic projections to the medial preoptic area of 
postpartum rats. Neuroscience, v. 159, p. 1384-1396, 2009.

MOGENSON, G.J.; JONES, D.L.; YIM, C.Y. From motivation to action: functional interface between the limbic system and the motor system. Prog. Neurobiol., v. 14, p. 69-97, 1980.

MOGENSON, G.J.; SWANSON, L.W.; WU, M. Neural projections from nucleus accumbens to globus pallidus, substantia innominata, and lateral preoptic-lateral hypothalamic area: an anatomical and electrophysiological investigation in the rat. J. Neurosci., v. 3, p. 189-202, 1983.

MORTON, G.J.; CUMMINGS, D.E.; BASKIN, D.G.; BARSH, G.S.; SCHWARTZ, M.W. Central nervous system control of food intake and body weight. Nature, v. 443, p. 289-295, 2006.

MORUTTO, S.L.; PHILLIPS, G.D. Interactions between sulpiride infusions within the perifornical region of the lateral hypothalamus and the nucleus accumbens on measures of locomotor activity and conditioned place preference. Behav. Pharmacol., v. 9, p. 345-355, 1998.

MORUZZI, G. The sleep-waking cycle. JOUVET, M.; MORUZZI, G. (Ed.). Ergebnisse der Physiologie. Reviews of Physiology. Heidelberg: New York, 1972.

MURRAY, B.; SHIZGAL, P. Attenuation of medical forebrain bundle reward by anterior lateral hypothalamic lesions. Behav. Brain Res., v. 75, p. 33-47, 1996.

NAKAMURA, T.; URAMURA, K.; NAMBU, T.; YADA, T.; GOTO, K.; YANAGISAWA, M.; SAKURAI, T. Orexin-induced hyperlocomotion and stereotypy are mediated by the dopaminergic system. Brain Res., v. 873, p. 181-187, 2000.

NALEID, A.M.; GRACE, M.K.; CUMMINGS, D.E.; LEVINE, A.S. Ghrelin induces feeding in the mesolimbic reward pathway between the ventral tegmental area and the nucleus accumbens. Peptides, v. 26, p. 2274-2279, 2005.

NARITA, M.; NAGUMO, Y.; HASHIMOTO, S.; KHOTIB, J.; MIYATAKE, M.; SAKURAI, T.; YANAGISAWA, M.; NAKAMACHI, T.; SHIODA, S.; SUZUKI, T. Direct involvement of orexinergic systems in the activation of the mesolimbic dopamine pathway and related behaviors induced by morphine. J. Neurosci., v. 26, p. 398-405, 2006.

NAUTA, W.J.; SMITH, G.P.; FAULL, R.L.; DOMESICK, V.B. Efferent connections and nigral afferents of the nucleus accumbens septi in the rat. Neuroscience, v. 3, p. 385-401, 1978.

NAUTA, W.J.H.; DOMESICK, V.B. Cross roads of limbic and striatal circuitry: hypothalamo-nigral connections. In: LIVINGSTON, K.E.; HORNYKIEWICZ, O. (Ed.). Limbic mechanisms: the continuing evolution of the limbic system concept. New York: Plenum Press, 1978. p. 75-93.

NESTLER, E.J.; BERHOW, M.T.; BRODKIN, E.S. Molecular mechanisms of drug addiction: adaptations in signal transduction pathways. Mol. Psychiatry, v. 1, p. 190-199, 1996. 
NIAURA, R.; CLARK, M.M.; RACITI, M.A.; PERA, V.; ABRAMS, D.B. Increased saliva cotinine concentrations in smokers during rapid weight loss. J. Consult Clin. Psychol., v. 60, p. $985-987,1992$.

NISWENDER, K.D.; MORTON, G.J.; STEARNS, W.H.; RHODES, C.J.; MYERS, M.G., JR.; SCHWARTZ, M.W. Intracellular signalling. Key enzyme in leptin-induced anorexia. Nature, v. 413, p. 794-795, 2001.

NISWENDER, K.D.; SCHWARTZ, M.W. Insulin and leptin revisited: adiposity signals with overlapping physiological and intracellular signaling capabilities. Front. Neuroendocrinol., v. 24, p. 1-10, 2003.

NISWENDER, K.D.; GALLIS, B.; BLEVINS, J.E.; CORSON, M.A.; SCHWARTZ, M.W.; BASKIN, D.G. Immunocytochemical detection of phosphatidylinositol 3-kinase activation by insulin and leptin. J. Histochem. Cytochem., v. 51, p. 275-283, 2003 a.

NISWENDER, K.D.; MORRISON, C.D.; CLEGG, D.J.; OLSON, R.; BASKIN, D.G.; MYERS, M.G., JR.; SEELEY, R.J.; SCHWARTZ, M.W. Insulin activation of phosphatidylinositol 3-kinase in the hypothalamic arcuate nucleus: a key mediator of insulininduced anorexia. Diabetes, v. 52, p. 227-231, 2003 b.

NISWENDER, K.D.; BASKIN, D.G.; SCHWARTZ, M.W. Insulin and its evolving partnership with leptin in the hypothalamic control of energy homeostasis. Trends Endocrinol. Metab., v. 15, p. 362-369, 2004.

NUMAN, S.; RUSSELL, D.S. Discrete expression of insulin receptor substrate-4 mRNA in adult rat brain. Brain Res. Mol. Brain Res., v. 72, p. 97-102, 1999.

OADES, R.D.; HALLIDAY, G.M. Ventral tegmental (A10) system: neurobiology. 1. Anatomy and connectivity. Brain Res., v. 434, p. 117-165, 1987.

OHTA, H.; NAKAMURA, S.; WATANABE, S.; UEKI, S. Effect of L-glutamate, injected into the posterior hypothalamus, on blood pressure and heart rate in unanesthetized and unrestrained rats. Neuropharmacology, v. 24, p. 445-451, 1985.

OLSON, V.G.; ZABETIAN, C.P.; BOLANOS, C.A.; EDWARDS, S.; BARROT, M.; EISCH, A.J.; HUGHES, T.; SELF, D.W.; NEVE, R.L.; NESTLER, E.J. Regulation of drug reward by cAMP response element-binding protein: evidence for two functionally distinct subregions of the ventral tegmental area. J. Neurosci., v. 25, p. 5553-5562, 2005.

OLSON, V.G.; NESTLER, E.J. Topographical organization of GABAergic neurons within the ventral tegmental area of the rat. Synapse, v. 61, p. 87-95, 2007.

OMELCHENKO, N.V.; SESACK, S.R. Ultrastructural evidence that non-dopamine cells in the rat ventral tegmental area synapse locally onto dopamine and GABA neurons. Society for Neuroscience 2006, out. 2006, Atlanta, Georgia, EUA. Abstract...Online.

PALKOVITS, M.; BROWNSTEIN, M.; SAAVEDRA, J.M.; AXELROD, J. Norepinephrine and dopamine content of hypothalamic nuclei of the rat. Brain Res., v. 77, p. 137-149, 1974. 
PALOVCIK, R.A.; PHILLIPS, M.I.; KAPPY, M.S.; RAIZADA, M.K. Insulin inhibits pyramidal neurons in hippocampal slices. Brain Res., v. 309, p. 187-191, 1984.

PARADA, M.A.; HERNANDEZ, L.; SCHWARTZ, D.; HOEBEL, B.G. Hypothalamic infusion of amphetamine increases serotonin, dopamine and norepinephrine. Physiol. Behav., v. 44, p. 607-610, 1988.

PARADA, M.A.; PUIG DE PARADA, M.; HOEBEL, B.G. Rats self-inject a dopamine antagonist in the lateral hypothalamus where it acts to increase extracellular dopamine in the nucleus accumbens. Pharmacol. Biochem. Behav., v. 52, p. 179-187, 1995.

PARDINI, A.W.; NGUYEN, H.T.; FIGLEWICZ, D.P.; BASKIN, D.G.; WILLIAMS, D.L.; KIM, F.; SCHWARTZ, M.W. Distribution of insulin receptor substrate-2 in brain areas involved in energy homeostasis. Brain Res., v. 1112, p. 169-178, 2006.

PARK, T.H.; CARR, K.D. Neuroanatomical patterns of fos-like immunoreactivity induced by a palatable meal and meal-paired environment in saline- and naltrexone-treated rats. Brain Res., v. 805, p. 169-180, 1998.

PARK, C.R. Cognitive effects of insulin in the central nervous system. Neurosci. Biobehav. Rev., v. 25, p. 311-323, 2001.

PAXINOS, G.; WATSON, C. The rat brain in stereotaxic coordinates. Amsterdam: Elsevier, 2007, $6^{\text {th }}$ edition.

PERROTTI, L.I.; BOLANOS, C.A.; CHOI, K.H.; RUSSO, S.J.; EDWARDS, S.; ULERY, P.G.; WALLACE, D.L.; SELF, D.W.; NESTLER, E.J.; BARROT, M. DeltaFosB accumulates in a GABAergic cell population in the posterior tail of the ventral tegmental area after psychostimulant treatment. Eur. J. Neurosci., v. 21, p. 2817-2824, 2005.

PEYRON, C.; TIGHE, D.K.; VAN DEN POL, A.N.; DE LECEA, L.; HELLER, H.C.; SUTCLIFFE, J.G.; KILDUFF, T.S. Neurons containing hypocretin (orexin) project to multiple neuronal systems. J. Neurosci., v. 18, p. 9996-10015, 1998.

PHILLIPSON, O.T. A Golgi study of the ventral tegmental area of Tsai and interfascicular nucleus in the rat. J. Comp. Neurol., v. 187, p. 99-115, 1979a.

PHILLIPSON, O.T. Afferent projections to the ventral tegmental area of Tsai and interfascicular nucleus: a horseradish peroxidase study in the rat. J. Comp. Neurol., v. 187, p. 117-143, 1979b.

PHILLIPS, M.I.; PALOVCIK, R.A. Dose-response testing of peptides by hippocampal brain slice recording. Methods Enzymol., v. 168, p. 129-144, 1989.

PINTO, S.; ROSEBERRY, A.G.; LIU, H.; DIANO, S.; SHANABROUGH, M.; CAI, X.; FRIEDMAN, J.M.; HORVATH, T.L. Rapid rewiring of arcuate nucleus feeding circuits by leptin. Science, v. 304, p. 110-115, 2004.

PIZZI, M.; COEN, E.; MEMO, M.; MISSALE, C.; CARRUBA, M.O.; SPANO, P.F. Evidence for the presence of D2 but not D1 dopamine receptors in rat hypothalamic 
perifornical area. Neurosci. Lett., v. 67, p. 159-162, 1986.

PLUM, L.; SCHUBERT, M.; BRUNING, J.C. The role of insulin receptor signaling in the brain. Trends Endocrinol. Metab., v. 16, p. 59-65, 2005.

POLSTON, E.K.; ERSKINE, M.S. Patterns of induction of the immediate-early genes c-fos and egr-1 in the female rat brain following differential amounts of mating stimulation. Neuroendocrinology, v. 62, p. 370-384, 1995.

PU, S.; JAIN, M.R.; KALRA, P.S.; KALRA, S.P. Orexins, a novel family of hypothalamic neuropeptides, modulate pituitary luteinizing hormone secretion in an ovarian steroiddependent manner. Regul. Pept., v. 78, p. 133-136, 1998.

QU, D.; LUDWIG, D.S.; GAMMELTOFT, S.; PIPER, M.; PELLEYMOUNTER, M.A.; CULLEN, M.J.; MATHES, W.F.; PRZYPEK, R.; KANAREK, R.; MARATOS-FLIER, E. A role for melanin-concentrating hormone in the central regulation of feeding behaviour. Nature, v. 380, p. 243-247, 1996.

RADA, P.; TUCCI, S.; MURZI, E.; HERNANDEZ, L. Extracellular glutamate increases in the lateral hypothalamus and decreases in the nucleus accumbens during feeding. Brain Res., v. 768, p. 338-340, 1997.

RICARDO, J.A.; KOH, E.T. Anatomical evidence of direct projections from the nucleus of the solitary tract to the hypothalamus, amygdala, and other forebrain structures in the rat. Brain Res., v. 153, p. 1-26, 1978.

RIEDIGER, T.; ZUEND, D.; BECSKEI, C.; LUTZ, T.A. The anorectic hormone amylin contributes to feeding-related changes of neuronal activity in key structures of the gut-brain axis. Am. J. Physiol. Regul. Integr. Comp. Physiol., v. 286, p. R114-122, 2004.

RODD-HENRICKS, Z.A.; MCKINZIE, D.L.; CRILE, R.S.; MURPHY, J.M.; MCBRIDE, W.J. Regional heterogeneity for the intracranial self-administration of ethanol within the ventral tegmental area of female Wistar rats. Psychopharmacology (Berl.), v. 149, p. 217$224,2000$.

ROTHWELL, N.J. CNS regulation of thermogenesis. Crit. Rev. Neurobiol., v. 8, p. 1-10, 1994.

RUSHING, P.A.; HAGAN, M.M.; SEELEY, R.J.; LUTZ, T.A.; WOODS, S.C. Amylin: a novel action in the brain to reduce body weight. Endocrinology, v. 141, p. 850-853, 2000.

RUSSO, S.J.; BOLANOS, C.A.; THEOBALD, D.E.; DECAROLIS, N.A.; RENTHAL, W.; KUMAR, A.; WINSTANLEY, C.A.; RENTHAL, N.E.; WILEY, M.D.; SELF, D.W.; RUSSELL, D.S.; NEVE, R.L.; EISCH, A.J.; NESTLER, E.J. IRS2-Akt pathway in midbrain dopamine neurons regulates behavioral and cellular responses to opiates. Nat. Neurosci., v. 10, p. 93-99, 2007.

SAITO, Y.; NOTHACKER, H.P.; WANG, Z.; LIN, S.H.; LESLIE, F.; CIVELLI, O. Molecular characterization of the melanin-concentrating-hormone receptor. Nature, v. 400, p. 265-269, 1999. 
SAKATA, I.; NAKAMURA, K.; YAMAZAKI, M.; MATSUBARA, M.; HAYASHI, Y.; KANGAWA, K.; SAKAI, T. Ghrelin-producing cells exist as two types of cells, closed- and opened-type cells, in the rat gastrointestinal tract. Peptides, v. 23, p. 531-536, 2002.

SAKURAI, T.; AMEMIYA, A.; ISHII, M.; MATSUZAKI, I.; CHEMELLI, R.M.; TANAKA, H.; WILLIAMS, S.C.; RICHARSON, J.A.; KOZLOWSKI, G.P.; WILSON, S.; ARCH, J.R.; BUCKINGHAM, R.E.; HAYNES, A.C.; CARR, S.A.; ANNAN, R.S.; MCNULTY, D.E.; LIU, W.S.; TERRETT, J.A.; ELSHOURBAGY, N.A.; BERGSMA, D.J.; YANAGISAWA, M. Orexins and orexin receptors: a family of hypothalamic neuropeptides and $\mathrm{G}$ protein-coupled receptors that regulate feeding behavior. Cell, v. 92, p. 1 page following 696, 1998.

SALAMONE, J.D.; CORREA, M. Motivational views of reinforcement: implications for understanding the behavioral functions of nucleus accumbens dopamine. Behav. Brain Res., v. 137, p. 3-25, 2002.

SALAMONE, J.D.; CORREA, M.; MINGOTE, S.M.; WEBER, S.M. Beyond the reward hypothesis: alternative functions of nucleus accumbens dopamine. Curr. Opin. Pharmacol., v. 5, p. 34-41, 2005.

SANO, H.; YOKOI, M. Striatal medium spiny neurons terminate in a distinct region in the lateral hypothalamic area and do not directly innervate orexin/hypocretin- or melaninconcentrating hormone-containing neurons. J. Neurosci., v. 27, p. 6948-6955, 2007.

SAPER, C.B.; LOEWY, A.D. Efferent connections of the parabrachial nucleus in the rat. Brain Res., v. 197, p. 291-317, 1980.

SAPER, C.B.; CHOU, T.C.; ELMQUIST, J.K. The need to feed: homeostatic and hedonic control of eating. Neuron, v. 36, p. 199-211, 2002.

SAWCHENKO, P.E.; SWANSON, L.W. The organization of noradrenergic pathways from the brainstem to the paraventricular and supraoptic nuclei in the rat. Brain Res., v. 257, p. 275-325, 1982.

SAWCHENKO, P.E.; SWANSON, L.W. The organization of forebrain afferents to the paraventricular and supraoptic nuclei of the rat. J. Comp. Neurol., v. 218, p. 121-144, 1983.

SCAMMELL, T.E.; PRICE, K.J.; SAGAR, S.M. Hyperthermia induces c-fos expression in the preoptic area. Brain Res., v. 618, p. 303-307, 1993.

SCHEIBNER, T.; TORK, I. Ventromedial mesencephalic tegmental (VMT) projections to ten functionally different cortical areas in the cat: topography and quantitative analysis. $\mathbf{J}$. Comp. Neurol., v. 259, p. 247-265, 1987.

SCHULTZ, W. Predictive reward signal of dopamine neurons. J. Neurophysiol., v. 80, p. 127, 1998.

SCHWARTZ, M.W.; FIGLEWICZ, D.P.; BASKIN, D.G.; WOODS, S.C.; PORTE, D., JR. Insulin in the brain: a hormonal regulator of energy balance. Endocr. Rev., v. 13, p. 387-414, 1992. 
SESACK, S.R.; GRACE, A.A. Cortico-Basal Ganglia Reward Network: Microcircuitry. Neuropsychopharmacology, v. p. 2009.

SEXTON, P.M.; PAXINOS, G.; KENNEY, M.A.; WOOKEY, P.J.; BEAUMONT, K. In vitro autoradiographic localization of amylin binding sites in rat brain. Neuroscience, v. 62, p. 553-567, 1994.

SHALEV, U.; YAP, J.; SHAHAM, Y. Leptin attenuates acute food deprivation-induced relapse to heroin seeking. J. Neurosci., v. 21, p. RC129, 2001.

SHERIN, J.E.; SHIROMANI, P.J.; MCCARLEY, R.W.; SAPER, C.B. Activation of ventrolateral preoptic neurons during sleep. Science, v. 271, p. 216-219, 1996.

SHIMADA, M.; TRITOS, N.A.; LOWELL, B.B.; FLIER, J.S.; MARATOS-FLIER, E. Mice lacking melanin-concentrating hormone are hypophagic and lean. Nature, v. 396, p. 670-674, 1998.

SIMON, H.; LE MOAL, M.; GALEY, D.; CARDO, B. Silver impregnation of dopaminergic systems after radiofrequency and 6-OHDA lesions of the rat ventral. Brain Res., v. 115, p. 215-231, 1976.

SIMON, H.; LE MOAL, M.; CALAS, A. Efferents and afferents of the ventral tegmentalA10 region studied after local injection of $[3 \mathrm{H}]$ leucine and horseradish peroxidase. Brain Res., v. 178, p. 17-40, 1979.

SIMERLY, R.B.; SWANSON, L.W. The organization of neural inputs to the medial preoptic nucleus of the rat. J. Comp. Neurol., v. 246, p. 312-342, 1986.

SIPOLS, A.J.; STUBER, G.D.; KLEIN, S.N.; HIGGINS, M.S.; FIGLEWICZ, D.P. Insulin and raclopride combine to decrease short-term intake of sucrose solutions. Peptides, v. 21, p. 1361-1367, 2000.

SPANSWICK, D.; SMITH, M.A.; GROPPI, V.E.; LOGAN, S.D.; ASHFORD, M.L. Leptin inhibits hypothalamic neurons by activation of ATP-sensitive potassium channels. Nature, v. 390, p. 521-525, 1997.

SPENCER, S.E.; SAWYER, W.B.; LOEWY, A.D. L-glutamate mapping of cardioreactive areas in the rat posterior hypothalamus. Brain Res., v. 511, p. 149-157, 1990.

SRIVIDYA, R.; MALLICK, H.N.; KUMAR, V.M. Differences in the effects of medial and lateral preoptic lesions on thermoregulation and sleep in rats. Neuroscience, v. 139, p. 853864, 2006.

STANLEY, B.G.; HA, L.H.; SPEARS, L.C.; DEE, M.G., 2nd. Lateral hypothalamic injections of glutamate, kainic acid, D,L-alpha-amino-3-hydroxy-5-methyl-isoxazole propionic acid or N-methyl-D-aspartic acid rapidly elicit intense transient eating in rats. Brain Res., v. 613, p. 88-95, 1993a.

STANLEY, B.G.; WILLETT, V.L., 3RD; DONIAS, H.W.; HA, L.H.; SPEARS, L.C. The 
lateral hypothalamus: a primary site mediating excitatory amino acid-elicited eating. Brain Res., v. 630, p. 41-49, 1993 b.

STANLEY, B.G.; WILLETT, V.L., 3RD; DONIAS, H.W.; DEE, M.G., 2ND; DUVA, M.A. Lateral hypothalamic NMDA receptors and glutamate as physiological mediators of eating and weight control. Am. J. Physiol., v. 270, p. R443-449, 1996.

STEFFENSEN, S.C.; SVINGOS, A.L.; PICKEL, V.M.; HENRIKSEN, S.J. Electrophysiological characterization of GABAergic neurons in the ventral tegmental area. $\mathbf{J}$. Neurosci., v. 18, p. 8003-8015, 1998.

STEFFENSEN, S.C.; STOBBS, S.H.; COLAGO, E.E.; LEE, R.S.; KOOB, G.F.; GALLEGOS, R.A.; HENRIKSEN, S.J. Contingent and non-contingent effects of heroin on mu-opioid receptor-containing ventral tegmental area GABA neurons. Exp. Neurol., v. 202, p. 139-151, 2006.

STELLAR, E. The physiology of motivation. Psychol. Rev., v. 61, p. 5-22, 1954.

STOBBS, S.H.; OHRAN, A.J.; LASSEN, M.B.; ALLISON, D.W.; BROWN, J.E.; STEFFENSEN, S.C. Ethanol suppression of ventral tegmental area GABA neuron electrical transmission involves N-methyl-D-aspartate receptors. J. Pharmacol. Exp. Ther., v. 311, p. 282-289, 2004.

STRATFORD, T.R.; KELLEY, A.E. Evidence of a functional relationship between the nucleus accumbens shell and lateral hypothalamus subserving the control of feeding behavior. J. Neurosci., v. 19, p. 11040-11048, 1999.

STRATFORD, T.R.; KELLEY, A.E.; SIMANSKY, K.J. Blockade of GABAA receptors in the medial ventral pallidum elicits feeding in satiated rats. Brain Res., v. 825, p. 199-203, 1999.

SWANSON, L.W. An autoradiographic study of the efferent connections of the preoptic region in the rat. J. Comp. Neurol., v. 167, p. 227-256, 1976.

SWANSON, L.W. The projections of the ventral tegmental area and adjacent regions: a combined fluorescent retrograde tracer and immunofluorescence study in the rat. Brain Res. Bull., v. 9, p. 321-353, 1982.

SWANSON, L.W.; SANCHEZ-WATTS, G.; WATTS, A.G. Comparison of melaninconcentrating hormone and hypocretin/orexin mRNA expression patterns in a new parceling scheme of the lateral hypothalamic zone. Neurosci. Lett., v. 387, p. 80-84, 2005.

TAKAHASHI, M.; YAMADA, T.; TOOYAMA, I.; MOROO, I.; KIMURA, H.; YAMAMOTO, T.; OKADA, H. Insulin receptor mRNA in the substantia nigra in Parkinson's disease. Neurosci. Lett., v. 204, p. 201-204, 1996.

TAMEMOTO, H.; KADOWAKI, T.; TOBE, K.; YAGI, T.; SAKURA, H.; HAYAKAWA, T.; TERAUCHI, Y.; UEKI, K.; KABURAGI, Y.; SATOH, S.; SEKIHARA, H.; YOSHIOKA, S.; HORIKOSHI, H.; FURUTA, Y.; IKAWA, Y.; KASUGA, M.; YAZAKI, 
Y.; AIZAWA, S. Insulin resistance and growth retardation in mice lacking insulin receptor substrate-1. Nature, v. 372, p. 182-186, 1994.

THOMPSON, R.H.; CANTERAS, N.S.; SWANSON, L.W. Organization of projections from the dorsomedial nucleus of the hypothalamus: a PHA-L study in the rat. J. Comp. Neurol., v. 376, p. 143-173, 1996.

THOMPSON, R.H.; SWANSON, L.W. Organization of inputs to the dorsomedial nucleus of the hypothalamus: a reexamination with Fluorogold and PHAL in the rat. Brain Res. Brain Res. Rev., v. 27, p. 89-118, 1998.

THOMPSON, R.H.; SWANSON, L.W. Structural characterization of a hypothalamic visceromotor pattern generator network. Brain Res. Brain Res. Rev., v. 41, p. 153-202, 2003.

THORPE, A.J.; MUlletT, M.A.; WANG, C.; KOTZ, C.M. Peptides that regulate food intake: regional, metabolic, and circadian specificity of lateral hypothalamic orexin A feeding stimulation. Am. J. Physiol. Regul. Integr. Comp. Physiol., v. 284, p. R1409-1417, 2003.

THORPE, A.J.; DOANE, D.F.; SWEET, D.C.; BEVERLY, J.L.; KOTZ, C.M. Orexin A in the rostrolateral hypothalamic area induces feeding by modulating GABAergic transmission. Brain Res., v. 1125, p. 60-66, 2006.

TOSHINAI, K.; DATE, Y.; MURAKAMI, N.; SHIMADA, M.; MONDAL, M.S.; SHIMBARA, T.; GUAN, J.L.; WANG, Q.P.; FUNAHASHI, H.; SAKURAI, T.; SHIODA, S.; MATSUKURA, S.; KANGAWA, K.; NAKAZATO, M. Ghrelin-induced food intake is mediated via the orexin pathway. Endocrinology, v. 144, p. 1506-1512, 2003.

TRIVEDI, P.; YU, H.; MACNEIL, D.J.; VAN DER PLOEG, L.H.; GUAN, X.M. Distribution of orexin receptor mRNA in the rat brain. FEBS Lett., v. 438, p. 71-75, 1998.

UNGER, J.; MCNEILL, T.H.; MOXLEY, R.T., 3RD; WHITE, M.; MOSS, A.; LIVINGSTON, J.N. Distribution of insulin receptor-like immunoreactivity in the rat forebrain. Neuroscience, v. 31, p. 143-157, 1989.

UNGER, J.W.; LIVINGSTON, J.N.; MOSS, A.M. Insulin receptors in the central nervous system: localization, signalling mechanisms and functional aspects. Prog. Neurobiol., v. 36, p. 343-362, 1991.

UNGERSTEDT, U. Adipsia and aphagia after 6-hydroxydopamine induced degeneration of the nigro-striatal dopamine system. Acta Physiol. Scand. Suppl., v. 367, p. 95-122, 1971.

URAMURA, K.; FUNAHASHI, H.; MUROYA, S.; SHIODA, S.; TAKIGAWA, M.; YADA, $\mathrm{T}$. Orexin-a activates phospholipase $\mathrm{C}$ - and protein kinase $\mathrm{C}$-mediated $\mathrm{Ca} 2+$ signaling in dopamine neurons of the ventral tegmental area. Neuroreport., v. 12, p. 1885-1889, 2001.

USUDA, I.; TANAKA, K.; CHIBA, T. Efferent projections of the nucleus accumbens in the rat with special reference to subdivision of the nucleus: biotinylated dextran amine study. Brain Res., v. 797, p. 73-93, 1998. 
VAN DONGEN,Y.C.; DENIAU, J.M.; PENNARTZ, C.M.; GALIS-DE GRAAF, Y.; VOORN, P.; THIERRY, A.M.; GROENEWEGEN, H.J. Anatomical evidence for direct connections between the shell and core subregions of the rat nucleus accumbens. Neuroscience, v. 136, p. 1049-1071, 2005.

VAN FURTH, W.R.; VAN EMST, M.G.; VAN REE, J.M. Opioids and sexual behavior of male rats: involvement of the medial preoptic area. Behav. Neurosci., v. 109, p. 123-134, 1995.

VEENING, J.G.; SWANSON, L.W.; COWAN, W.M.; NIEUWENHUYS, R.; GEERAEDTS, L.M. The medial forebrain bundle of the rat. II. An autoradiographic study of the topography of the major descending and ascending components. J. Comp. Neurol., v. 206, p. 82-108, 1982.

VERTES, R.P. Brainstem afferents to the basal forebrain in the rat. Neuroscience, v. 24, p. 907-935, 1988.

VERTES, R.P.; CRANE, A.M.; COLOM, L.V.; BLAND, B.H. Ascending projections of the posterior nucleus of the hypothalamus: PHA-L analysis in the rat. J. Comp. Neurol., v. 359, p. 90-116, 1995.

VERTES, R.P.; CRANE, A.M. Descending projections of the posterior nucleus of the hypothalamus: Phaseolus vulgaris leucoagglutinin analysis in the rat. J. Comp. Neurol., v. 374, p. 607-631, 1996.

VIAU, V.; MEANEY, M.J. The inhibitory effect of testosterone on hypothalamic-pituitaryadrenal responses to stress is mediated by the medial preoptic area. J. Neurosci., v. 16, p. 1866-1876, 1996.

WAGNER, C.K.; EATON, M.J.; MOORE, K.E.; LOOKINGLAND, K.J. Efferent projections from the region of the medial zona incerta containing A13 dopaminergic neurons: a PHA-L anterograde tract-tracing study in the rat. Brain Res., v. 677, p. 229-237, 1995.

WALDROP, T.G.; BAUER, R.M.; IWAMOTO, G.A. Microinjection of GABA antagonists into the posterior hypothalamus elicits locomotor activity and a cardiorespiratory activation. Brain Res., v. 444, p. 84-94, 1988.

WILlIAMS, G.; BING, C.; CAI, X.J.; HARROLD, J.A.; KING, P.J.; LIU, X.H. The hypothalamus and the control of energy homeostasis: different circuits, different purposes. Physiol. Behav., v. 74, p. 683-701, 2001.

WILSON, C.; NOMIKOS, G.G.; COLLU, M.; FIBIGER, H.C. Dopaminergic correlates of motivated behavior: importance of drive. J. Neurosci., v. 15, p. 5169-5178, 1995.

WISE, R.A.; ROMPRE, P.P. Brain dopamine and reward. Annu. Rev. Psychol., v. 40, p. 191-225, 1989.

WITHERS, D.J.; GUTIERREZ, J.S.; TOWERY, H.; BURKS, D.J.; REN, J.M.; PREVIS, S.; ZHANG, Y.; BERNAL, D.; PONS, S.; SHULMAN, G.I.; BONNER-WEIR, S.; WHITE, 
M.F. Disruption of IRS-2 causes type 2 diabetes in mice. Nature, v. 391, p. 900-904, 1998.

WOLF, D.H.; NUMAN, S.; NESTLER, E.J.; RUSSELL, D.S. Regulation of phospholipase Cgamma in the mesolimbic dopamine system by chronic morphine administration. $\mathbf{J}$. Neurochem., v. 73, p. 1520-1528, 1999.

WOODS, S.C.; FIGLEWICZ LATTEMANN, D.P.; SCHWARTZ, M.W.; PORTE, D., JR. A re-assessment of the regulation of adiposity and appetite by the brain insulin system. Int. J. Obes., v. 14 Suppl 3, p. 69-73; discussion 74-66, 1990.

WOODS, S.C.; CHAVEZ, M.; PARK, C.R.; RIEDY, C.; KAIYALA, K.; RICHARDSON, R.D.; FIGLEWICZ, D.P.; SCHWARTZ, M.W.; PORTE, D., JR.; SEELEY, R.J. The evaluation of insulin as a metabolic signal influencing behavior via the brain. Neurosci. Biobehav. Rev., v. 20, p. 139-144, 1996.

WOODS, S.C.; SEELEY, R.J.; PORTE, D., JR.; SCHWARTZ, M.W. Signals that regulate food intake and energy homeostasis. Science, v. 280, p. 1378-1383, 1998.

YANG, Z.J.; MEGUID, M.M.; CHAI, J.K.; CHEN, C.; OLER, A. Bilateral hypothalamic dopamine infusion in male Zucker rat suppresses feeding due to reduced meal size. Pharmacol. Biochem. Behav., v. 58, p. 631-635, 1997.

YOSHIDA, K.; MCCORMACK, S.; ESPANA, R.A.; CROCKER, A.; SCAMMELL, T.E. Afferents to the orexin neurons of the rat brain. J. Comp. Neurol., v. 494, p. 845-861, 2006.

YOSHIDA, K.; LI, X.; CANO, G.; LAZARUS, M.; SAPER, C.B. Parallel preoptic pathways for thermoregulation. J. Neurosci., v. 29, p. 11954-11964, 2009.

YURA, S.; OGAWA, Y.; SAGAWA, N.; MASUZAKI, H.; ITOH, H.; EBIHARA, K.; AIZAWA-ABE, M.; FUJII, S.; NAKAO, K. Accelerated puberty and late-onset hypothalamic hypogonadism in female transgenic skinny mice overexpressing leptin. J. Clin. Invest., v. 105, p. 749-755, 2000.

ZAHM, D.S.; HEIMER, L. Two transpallidal pathways originating in the rat nucleus accumbens. J. Comp. Neurol., v. 302, p. 437-446, 1990.

ZAHM, D.S.; WILLIAMS, E.; WOHLTMANN, C. Ventral striatopallidothalamic projection: IV. Relative involvements of neurochemically distinct subterritories in the ventral pallidum and adjacent parts of the rostroventral forebrain. J. Comp. Neurol., v. 364, p. 340-362, 1996.

ZAHM, D.S. An integrative neuroanatomical perspective on some subcortical substrates of adaptive responding with emphasis on the nucleus accumbens. Neurosci. Biobehav. Rev., v. 24, p. 85-105, 2000.

ZHAO, W.Q.; CHEN, H.; QUON, M.J.; ALKON, D.L. Insulin and the insulin receptor in experimental models of learning and memory. Eur. J. Pharmacol., v. 490, p. 71-81, 2004.

ZHENG, H.; PATTERSON, L.M.; BERTHOUD, H.R. Orexin signaling in the ventral tegmental area is required for high-fat appetite induced by opioid stimulation of the nucleus accumbens. J. Neurosci., v. 27, p. 11075-11082, 2007. 
ZHOU, Q.Y.; PALMITER, R.D. Dopamine-deficient mice are severely hypoactive, adipsic, and aphagic. Cell, v. 83, p. 1197-1209, 1995. 